\title{
Presenilins and $\gamma$-Secretase: Structure, Function, and Role in Alzheimer Disease
}

\author{
Bart De Strooper ${ }^{1,2}$, Takeshi Iwatsubo ${ }^{3}$, and Michael S. Wolfe ${ }^{4}$ \\ ${ }^{1}$ Center for Human Genetics, Leuven Institute for Neurodegenerative Diseases, KULeuven, 3000 \\ Leuven, Belgium \\ ${ }^{2}$ Department for Molecular and Developmental Genetics, VIB, 3000 Leuven, Belgium \\ ${ }^{3}$ Department of Neuropathology, Graduate School of Medicine, University of Tokyo, Tokyo 113-0033, Japan \\ ${ }^{4}$ Center for Neurologic Diseases, Brigham and Women's Hospital and Harvard Medical School, Boston, \\ Massachusetts 02115 \\ Correspondence: mwolfe@rics.bwh.harvard.edu
}

Presenilins were first discovered as sites of missense mutations responsible for early-onset Alzheimer disease (AD). The encoded multipass membrane proteins were subsequently found to be the catalytic components of $\gamma$-secretases, membrane-embedded aspartyl protease complexes responsible for generating the carboxyl terminus of the amyloid $\beta$-protein $(A \beta)$ from the amyloid protein precursor (APP). The protease complex also cleaves a variety of other type I integral membrane proteins, most notably the Notch receptor, signaling from which is involved in many cell differentiation events. Although $\gamma$-secretase is a top target for developing diseasemodifying AD therapeutics, interference with Notch signaling should be avoided. Compounds that alter $A \beta$ production by $\gamma$-secretase without affecting Notch proteolysis and signaling have been identified and are currently at various stages in the drug development pipeline.

\begin{abstract}
As described in Haas et al. (2011), the amyAloid protein precursor (APP) undergoes successive proteolysis by $\beta$ - and $\gamma$-secretases to produce the amyloid $\beta$-protein $(A \beta)$ that characteristically deposits in the brain in Alzheimer disease $(\mathrm{AD})$. Both of these proteases are top targets for AD drug discovery, although each presents challenges for developing safe and effective therapeutics. $\gamma$-Secretase is a large complex of four different integral membrane proteins, with presenilin as the catalytic component comprising an unusual membrane-embedded aspartyl protease. Herein, we describe the discovery of the $\gamma$-secretase components,
\end{abstract}

the biological functions of $\gamma$-secretase, as well as other roles of presenilin outside the protease complex, what is known so far about the structure of the complex, the role of $\gamma$-secretase in disease (especially in $\mathrm{AD}$ ), and the current status and direction of $\gamma$-secretase inhibitors and modulators as candidate AD therapeutics.

\section{THE IDENTIFICATION OF THE PRESENILINS AND THE OTHER $\gamma$-SECRETASE SUBUNITS}

The name " $\gamma$-secretase" was used for the first time in 1993 to describe the proteolytic activity that cleaves APP in the transmembrane domain

Editors: Dennis J. Selkoe, Eckhard Mandelkow, and David M. Holtzman

Additional Perspectives on The Biology of Alzheimer Disease available at www.perspectivesinmedicine.org

Copyright (C) 2012 Cold Spring Harbor Laboratory Press; all rights reserved; doi: 10.1101/cshperspect.a006304

Cite this article as Cold Spring Harb Perspect Med 2012;2:a006304 
B. De Strooper et al.

(TMD) (Haass and Selkoe 1993). It took about 10 years to identify all of the components of the molecular machine responsible for this cleavage (De Strooper 2003). The first step forward was in 1995 when two lines of genetic investigation merged unexpectedly into the identification of the presenilins. Analysis of families with inherited forms of $\mathrm{AD}$ were found to contain mutations in the until then unknown genes presenilin 1 (PSEN1; see Fig. 1 for protein sequence, topology, and sites of mutations) on chromosome 14q24.3 (Alzheimer's Disease Collaborative Group 1995; Sherrington et al. 1995) and presenilin 2 (PSEN2) on chromosome 1q42.2 (Levy-Lahad et al. 1995; Rogaev et al. 1995). A second line of genetic investigation, in the worm Caenorhabditis elegans, inde- pendently identified a presenilin gene as a suppressor of lin-12 gain-of-function mutants (Levitan and Greenwald 1995). lin-12 is the worm ortholog of Notch, a gene critical for cell signaling during development. Thus, presenilin was important in the pathogenesis of $\mathrm{AD}$ and at the same time for development by regulating Notch signaling. However, the link between these two functions remained unclear, and it was proposed that presenilins could act as a channel, a receptor, or a transporter protein or even affect tau phosphorylation and dysfunction.

The first clue to the role of presenilins in APP processing came from observations that AD-causing mutations in PSEN1 and PSEN2 (more than 150 different mutations in these

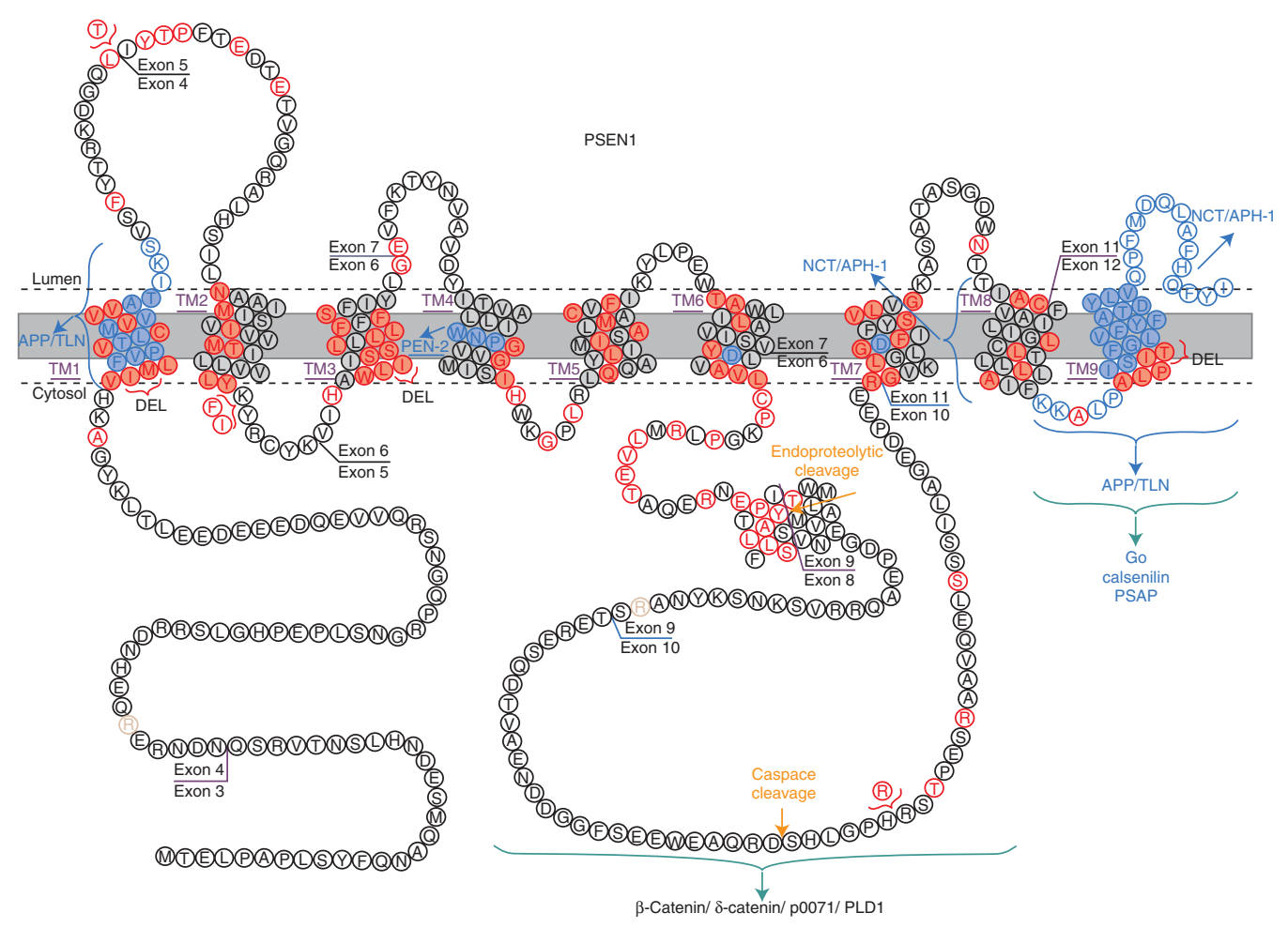

Figure 1. Amino acid sequence, topology, and mutations in presenilin 1. Single amino acid residues that have been found to be substituted by mutations causing familial $\mathrm{AD}$ are indicated in red. Exon/intron boundaries, the different transmembrane domains (TM1-TM9), residues (blue) involved in the interaction with amyloid precursor protein (APP), telencephalin (TLN), PEN-2, Nicastrin (NCT), and APH-1 are indicated with brackets. (This figure was adapted from Dillen and Annaert 2006; reprinted, with permission, from Elsevier (C) 2006. It is based on a figure published on the Alzforum website http://www.alzforum.org/res/com/mut/pre/ diagram1.asp.) 
genes have been identified) affect the generation of $A \beta$ peptides, changing the relative amount of A $\beta 42$ peptide $(\mathrm{A} \beta$ containing 42 amino acid residues) versus the shorter $A \beta 40$ (the more abundantly generated peptide, containing 40 amino acid residues; see Haas et al. 2011). This was shown in fibroblasts derived from patients (Scheuner et al. 1996), by overexpressing the mutant presenilins in cell lines (Borchelt et al. 1996; Citron et al. 1997), and by experiments in living mice, either overexpressing the mutant presenilin in brain using various promoters (Borchelt et al. 1996, 1997; Duff et al. 1996; Citron et al. 1997) or by knocking in mutations in the endogenous mouse presenilin gene (Siman et al. 2000; Flood et al. 2002).

The function of presenilin in the $\gamma$-secretase proteolytic activity became apparent when neurons were derived from PSEN1 knockout mice and used to show that PSEN1 was critically involved in the generation of all $\mathrm{A} \beta$ peptides (De Strooper et al. 1998). This experiment established presenilin as an important $\mathrm{AD}$ drug target (Haass and Selkoe 1998). The central role of presenilin in the $\gamma$-secretase processing of Notch was established a year later in mouse and Drosophila (De Strooper et al. 1999; Struhl and Greenwald 1999). Furthermore, because a $\gamma$-secretase inhibitor was shown to block not only APP processing but also Notch cleavage (De Strooper et al. 1999), it was suggested that a presenilin-dependent protease was responsible for both cleavages, and that blocking this enzyme would cause major side effects in patients. Notch is indeed not only involved in embryogenesis and development but also in differentiation of immune cells, the goblet cells in the intestine, and others (van Es et al. 2005).

At the same time, other studies suggested that presenilin was actually the catalytic subunit of $\gamma$-secretase. Site-directed mutagenesis of two aspartyl residues embedded in the TMDs VI and VII of PSEN1 resulted in a dominantnegative effect on $\gamma$-secretase activity, suggesting that presenilin was a protease, specifically of the aspartyl type (Wolfe et al. 1999b). These mutations did not affect the expression or the incorporation of presenilin into the $\gamma$-secretase complex (Nyabi et al. 2003), and are in a conserved region of the presenilin proteins (Steiner et al. 2000). They are found in a family of related intramembrane-cleaving proteases, the signal peptide peptidases (SPP) (Ponting et al. 2002; Weihofen et al. 2002). Finally, transition-state analog (i.e., active site-directed) $\gamma$-secretase inhibitors were shown to directly bind to the presenilin subunit of the $\gamma$-secretase complex (Esler et al. 2000; Li, Xu et al. 2000), providing convincing evidence that presenilin is indeed a protease.

In mammals, two homologous proteins exist, i.e., PSEN1 and PSEN2. They are both synthesized as precursor proteins of $50 \mathrm{kDa}$ with nine TMDs (Laudon et al. 2005; Spasic et al. 2006), and are cleaved into a $30 \mathrm{kDa}$ amino-terminal fragment (NTF) and a $20 \mathrm{kDa}$ carboxy-terminal fragment (CTF) during maturation (Thinakaran et al. 1996), probably by autocatalysis (Wolfe et al. 1999b,c; Fukumori et al. 2010).

Together with other proteases, presenilins represent a novel class of intramembranecleaving proteases or $i$-clips (Wolfe et al. 1999c; Wolfe and Kopan 2004). However, the presenilins are different from other $i$-clips, in the sense that they need three other protein subunits to achieve optimal activity. Early reports already suggested that it is not possible to overexpress presenilin in a functionally active way, as additional proteins ("limiting factors") are needed for presenilin to mature into stable NTF plus CTF heterodimers (Baumann et al. 1997; Thinakaran et al. 1997). The first "limiting" factor was coisolated in an immunochemical purification protocol using antibodies against presenilin. The resultant $130 \mathrm{kDa}$ type I integral membrane protein was baptized Nicastrin (Yu et al. 2000). The genes for Nicastrin and for the two other proteins of the $\gamma$-secretase complex were also identified independently in screens for modifiers of Notch homologs $g l p-1$ and lin-12 in C. elegans. Aph-1 (for "anterior pharynx-defective phenotype") is a $30 \mathrm{kDa}$ protein with 7 TMDs (Goutte et al. 2000; Levitan et al. 2001; Goutte et al. 2002), and Pen-2 (for "presenilin enhancer") is a $12 \mathrm{kDa}$ hairpinlike, two-transmembrane 
B. De Strooper et al.

protein (Francis et al. 2002). A series of reconstitution and knockdown experiments established that the four proteins (Fig. 2) are necessary and sufficient for $\gamma$-secretase processing (Edbauer et al. 2003; Kimberly et al. 2003; Takasugi et al. 2003). Both genetic screens (Francis et al. 2002) and recent purifications of the $\gamma$-secretase complex (Teranishi et al. 2009; Wakabayashi et al. 2009; Winkler et al. 2009) were not able to identify additional proteins stably associated with the complex, suggesting strongly that the core of the complex has been identified. Additional proteins might, however, be involved in the regulation of the activity or subcellular localization of the complex (Chen et al. 2006; Wakabayashi et al. 2009; He et al. 2010).

The stoichiometry of the $\gamma$-secretase complex is likely $1: 1: 1: 1$, based on molecular mass estimates in blue native electrophoresis (Kimberly et al. 2003), quantitative western blot analysis (Sato et al. 2007), and electron microscopy (EM) studies of the purified complex (Osenkowski et al. 2009). Thus, as there are two different PSEN genes and two different Aph1 genes (Aphla and Aph1b) encoded in the human genome, it follows that at least four different $\gamma$-secretase complexes exist (De Strooper
2003). The situation is actually even more complicated, as alternatively spliced forms for the presenilins and for Aph-1a have been reported (Alzheimer's Disease Collaborative Group 1995; Gu et al. 2003). The biological significance of this heterogeneity is only now being explored.

\section{THE BIOLOGICAL FUNCTIONS OF PRESENILIN}

As discussed, the main function of the presenilins is to provide the catalytic subunits to the different $\gamma$-secretases (De Strooper et al. 1998, 1999; Wolfe et al. 1999b; Esler et al. 2000; Li et al. 2000). Over the years, other presenilin functions have been proposed-in protein trafficking and turnover, in calcium homeostasis, in regulation of $\beta$-catenin signaling, and otherssometimes within and sometimes outside of the $\gamma$-secretase complex. These putatively "nonproteolytic" functions can be shown using presenilins in which the catalytic aspartyl residues (Wolfe et al. 1999b) are replaced by other amino acid residues and showing that a particular function is not dependent on these aspartyl residues. This criterion has been met in several

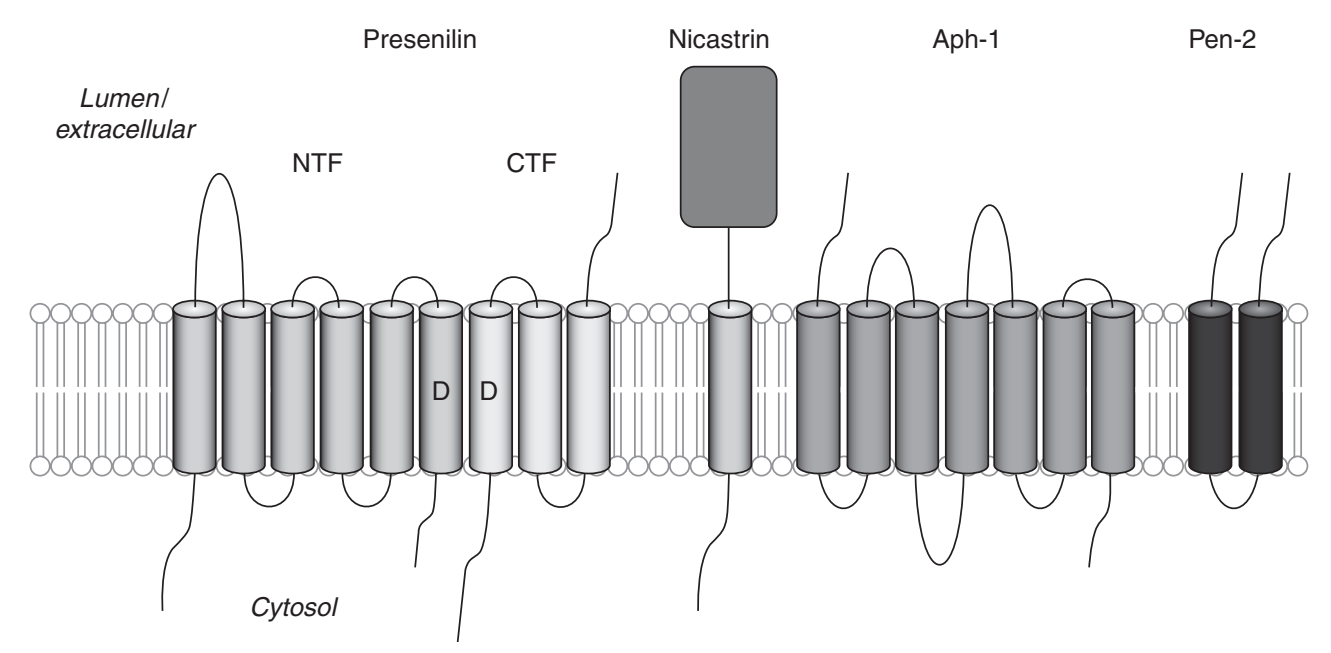

Figure 2. Subunits of the $\gamma$-secretase complex and their membrane topologies. Presenilin is proteolytically processed into two fragments during maturation of the complex, an amino-terminal fragment (NTF) and a carboxy-terminal fragment (CTF). The two transmembrane catalytic aspartic acid residues, one in the NTF and one in the CTF, are indicated by D. Other subunits are Nicastrin, APH-1, and PEN-2. 
instances, e.g., for the calcium leak function of presenilin in the endoplasmic reticulum (Tu et al. 2006; Nelson et al. 2007), for the growth alterations caused by deficiencies in cytoskeleton function in a presenilin-deficient variant of the moss Physcomitrella patens (Khandelwal et al. 2007), or in the turnover of the membrane protein telencephalin (Esselens et al. 2004).

To focus first on the proteolytic functions of $\gamma$-secretase (Fig. 3), the crucial and conserved role of presenilin in Notch signaling (Levitan and Greenwald 1995; De Strooper et al. 1999; Struhl and Greenwald 1999) has been repeatedly shown. In all species, severe developmental defects are associated with altered expression of Notch target genes such as the "hairy and enhancer of split" (HES) family. By using conditionally targeted alleles or partial knockouts of presenilin or else $\gamma$-secretase inhibitors, it is possible to evaluate the role of presenilin in Notch signaling in adulthood. Deficiencies in T- and B-cell differentiation (Doerfler et al. 2001; Hadland et al. 2001; Qyang et al. 2004; Tournoy et al. 2004; Wong et al. 2004), bloody diarrhea as a consequence of hampered intestinal goblet cell differentiation (Searfoss et al. 2003; Wong et al. 2004; van Es et al. 2005), and skin and hair defects (Xia et al. 2001; Tournoy et al. 2004), have been observed. Conditional knockout of presenilins in the forebrain (using an $\alpha$ CaMKII promoter to drive Cre expression) leads to progressive neurodegeneration, which has been proposed as an argument that loss of presenilin function could contribute to the pathogenesis of sporadic AD independently of affecting $A \beta_{42}$ generation (discussed in Shen and Kelleher 2007). However, the predictable absence of $A \beta$ deposition in these

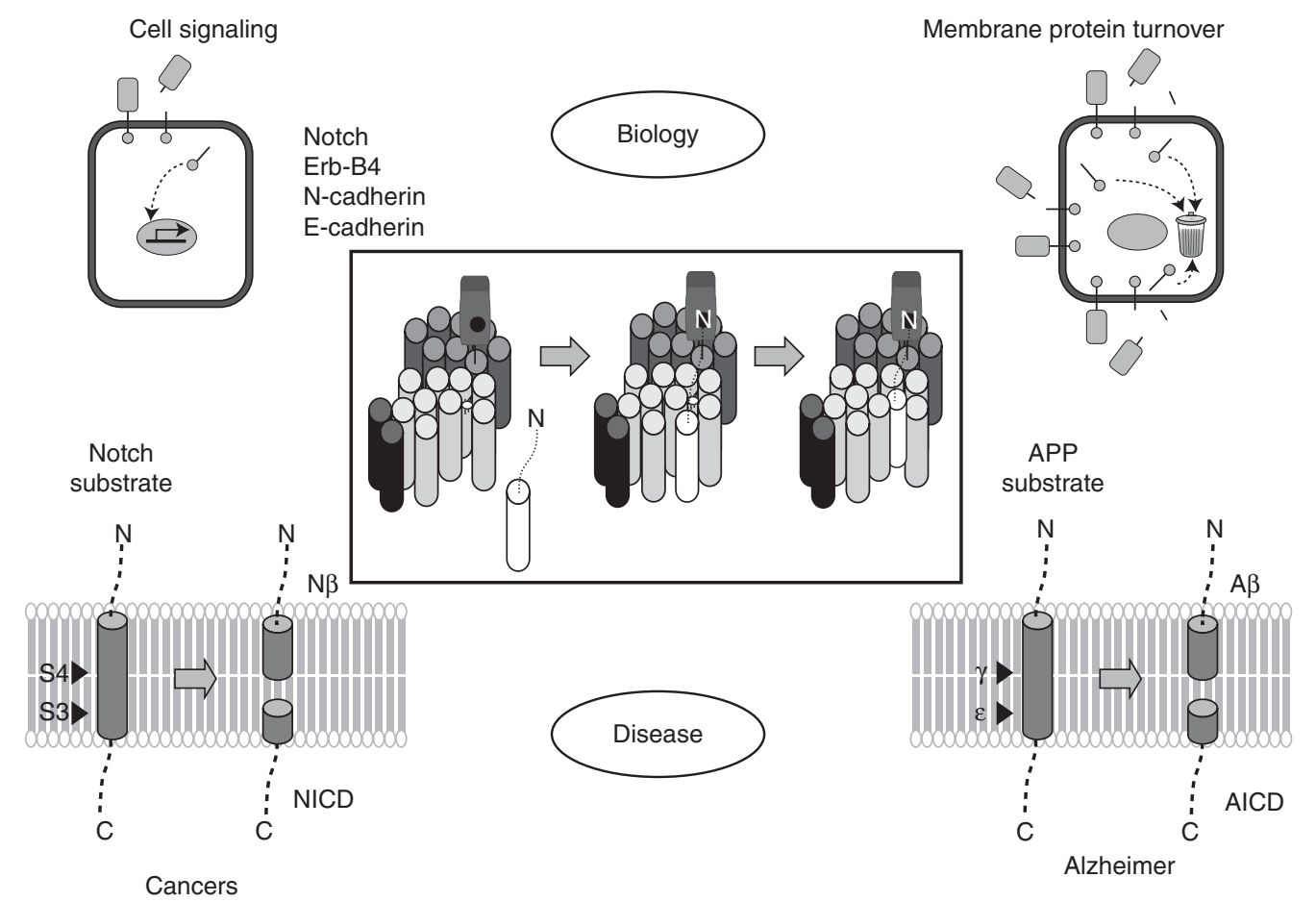

Figure 3. The role of the $\gamma$-secretase complex in biology and disease. Proteolytic processing of certain substrates (e.g., Notch, ErbB4, N-cadherin, E-cadherin) leads to cell signaling. Alternatively, processing of substrates by $\gamma$-secretase is simply a means of clearing protein stubs from the membrane. Excessive signaling from the Notch receptor leads to certain forms of cancer, and formation of the amyloid $\beta$-protein from its precursor APP by $\gamma$-secretase is involved in the pathogenesis of Alzheimer disease. 
knockout mice means that they do not constitute a model of AD.

It is clear that Notch phenotypes are predominant in presenilin-deficient animals, and interference with the Notch signaling pathway is the greatest concern when developing $\gamma$-secretase inhibitors to treat $\mathrm{AD}$ patients. However, over the years, more than 60 other proteins have been proposed as substrates for the $\gamma$-secretases (for an overview, see Hemming et al. 2008, Wakabayashi and De Strooper 2008, and McCarthy et al. 2009). Interestingly, the phenotypes of the mice in which individual subunits of $\gamma$-secretase (i.e., PSEN1 or PSEN2 and Aphla or Aph1b/c) have been knocked out are quite divergent, suggesting some specificity in the substrates cleaved by the different $\gamma$-secretase complexes in vivo. The Aph $1 \mathrm{~b} / \mathrm{c}$ containing $\gamma$-secretase complexes can, for instance, be completely removed from the mouse genome without causing any Notch defects, whereas similar inactivation of the Aphla-complexes leads to severe embryonic phenotypes (Ma et al. 2005; Serneels et al. 2005, 2009). Interestingly, Aph1b/c knockout mice display subtle behavioral phenotypes characterized by disturbed prepulse inhibition, increased amphetamine sensitivity, and alterations in an operational memory task (Dejaegere et al. 2008). Accumulation of neuregulin CTFs in brain extracts of these mice suggested that neuregulin is a substrate of Aph1b/c- $\gamma$-secretase. Similar phenotypes have been seen in neuregulin-deficient mice (Stefansson et al. 2002) and interestingly, also in BACE-1 knockout mice (Savonenko et al. 2008), in agreement with the fact that BACE-1 is the principal sheddase of neuregulin (Willem et al. 2006).

The biochemical evidence that the APP and its close relatives, amyloid precursor-like protein (APLP)- 1 and -2 are substrates of $\gamma$-secretase in vivo is also beyond discussion (De Strooper et al. 1998; Naruse et al. 1998; Scheinfeld et al. 2002; Eggert et al. 2004; Yanagida et al. 2009). As described in Müller and Zheng (2011), APP-deficient animals have yielded little direct information with regard to the specific molecular pathways for which APP is required, and it therefore remains unclear to what extent $\gamma$-secretase processing of APP (apart from generating the infamous $A \beta$ peptide) has biological consequences. $\gamma$-Secretase inactivation causes accumulation of APP carboxy-terminal fragments (APP-CTF) to levels which are two- to threefold higher than what is observed in wildtype cells, and $A \beta$ peptide is no longer produced. It is possible that the main role of $\gamma$-secretase processing of the APP membranebound fragments is to clear these hydrophobic remnants (Kopan and Ilagan 2004), although some evidence suggests that the released APP intracellular domain might be involved in signaling processes (critically discussed in Reinhard et al. 2005). Importantly, also in the context of the development of $\gamma$-secretase inhibitors for the clinic, it seems that additional clearance mechanisms can compensate for the loss of $\gamma$-secretase processing by removing APP CTFs via alternative pathways. Other substrates that have been well studied are the $\mathrm{N}$ - and E-cadherins. Presenilin-1 forms complexes with these proteins and the $\alpha$ - and $\beta$-catenins at the cell surface (Georgakopoulos et al. 1999). $\gamma$-Secretase proteolysis of E-cadherin results in the release of the associated $\beta$ - (and $\alpha$-) catenins and disassembly of the adherens junction (Marambaud et al. 2002). N-cadherin cleavage by $\gamma$-secretase is stimulated by NMDA agonists. The cleavage gives rise to an intracellular $\mathrm{N}$ cadherin fragment that binds to CBP (the cyclic AMP response element binding protein [CREB] binding protein) (Marambaud et al. 2003).

Presenilins have also been implicated in the cellular trafficking of proteins. Given the many substrates of presenilin, it is not unexpected that interference with proteolysis will lead to abnormal accumulation of protein fragments in the cell. However, a number of cell-surface proteins that are apparently not substrates of $\gamma$-secretase, including intercellular adhesion molecule 5 (ICAM5) or telencephalin (Esselens et al. 2004), epidermal growth factor receptor (EGFR) (Repetto et al. 2007), and $\beta 1$-integrins (Zou et al. 2008), are also mislocalized in presenilin-deficient cells. Defective transport between endosomes and lysosomes or other deficits in late endosomal or other degradative organelles have been proposed to explain the 
abnormal accumulation of these proteins in presenilin knockout cells (Esselens et al. 2004; Wilson et al. 2004; Repetto et al. 2007; Lee et al. 2010).

The role of presenilin in $\mathrm{Ca}^{2+}$ homeostasis is even more controversial. There is consensus that clinical mutations in presenilin disturb the $\mathrm{Ca}^{2+}$ pool at the level of the ER (Bezprozvanny and Mattson 2008). The mechanisms, however, are debated and include higher expression of the Ryanodine receptor (RyR) (Chan et al. 2000; Hayrapetyan et al. 2008), stimulation of inositol-3-phosphate (IP3)-induced ER $\mathrm{Ca}^{2+}$ release (Leissring et al. 1999; Kasri et al. 2006; Cheung et al. 2008), or stimulation of sarco(endo)plasmic reticulum $\mathrm{Ca}^{2+}$-ATPase (SERCA) pumps (Green et al. 2008). Presenilins might act as $\mathrm{Ca}^{2+}$ leak channels themselves ( $\mathrm{Tu}$ et al. 2006). This leakage function is only observed with fulllength presenilin-1 (i.e., before it becomes incorporated into the $\gamma$-secretase complex), and again, presenilin-containing aspartate mutations are able to maintain this function.

\section{STRUCTURE-FUNCTION RELATIONSHIP OF $\gamma$-SECRETASE}

The first step in understanding the structure of a membrane protein complex such as $\gamma$-secretase is to determine the membrane topology of the individual components. Presenilin 1 (PSEN1) and PSEN2 are integral membrane proteins that span membranes multiple times: Initially, the amino and carboxyl termini of PSEN1 and PSEN2 were predicted to be oriented to the cytoplasmic side (Doan et al. 1996), but a later $\mathrm{N}$-linked glycosylation scanning approach revealed that PSEN spans the membrane nine times, with amino and carboxyl termini being oriented to the cytoplasmic and luminal sides, respectively (Laudon et al. 2005). Nicastrin is a type I single-span membrane protein with a large extracellular domain, the latter being heavily glycosylated and tightly folded on maturation (Shirotani et al. 2003). Aph-1 is apparently a 7-TMD protein with its amino and carboxyl termini located on the luminal and cytoplasmic sides, respectively (Fortna et al. 2004). Pen-2 spans the membrane twice, with both the amino and carboxyl termini being found on the luminal side (Crystal et al. 2003).

Another fundamental issue toward elucidating the structure of the $\gamma$-secretase complex is determining its protein-protein contacts. Which components are bound to each other, and what are the binding domains? Nicastrin and Aph-1 form an initial subcomplex in the endoplasmic reticulum (LaVoie et al. 2003), and multiple TMDs of Aph-1 are involved in the binding to Nicastrin (Pardossi-Piquard et al. 2009; Chiang et al. 2010). The Nicastrin/ Aph-1 subcomplex then interacts with the PSEN and Pen-2 subcomplex (Fraering et al. 2004a). Site-directed mutagenesis combined with coimmunoprecipitation studies showed that the carboxy-terminal domain of PSEN interacts with the TMD of Nicastrin (Capell et al. 2003; Kaether et al. 2004). Aph-1 also directly interacts with the carboxy-terminal region of PSEN (Steiner et al. 2008). Binding of Pen-2 to PSEN occurs independently of the Nct/Aph-1 interaction (Fraering et al. 2004a). It has also been shown that PSEN1 interacts with Pen-2 through its fourth TMD (Kim and Sisodia 2005; Watanabe et al. 2005).

Because of the unique features of $\gamma$-secretase as a membrane-embedded protein complex harboring at least 19 membrane-spanning regions and executing intramembrane hydrolysis of substrate proteins, there is great interest in its precise structure. However, crystallization of the purified $\gamma$-secretase complex has not been achieved yet. Hence, a couple of indirect approaches have been conducted to begin to predict the structure of the complex. EM and single-particle image analysis on human $\gamma$-secretase complexes purified from mammalian cells revealed a cylindrical interior chamber of $\sim 20-40 \AA$ length, consistent with a proteolytic site occluded from the hydrophobic environment of the lipid bilayer. Lectin tagging of the Nicastrin ectodomain enabled proper orientation of the globular, $\sim 120 \AA$-long complex within the membrane (Lazarov et al. 2006). Further analysis of the structure of $\gamma$-secretase complex by cryoelectron microscopy and singleparticle image reconstruction at $12 \AA$ resolution revealed several domains on the extracellular 
side, three low-density cavities, and a surface groove in the transmembrane region of the complex (Osenkowski et al. 2009). Human $\gamma$-secretase complexes reconstituted in Sf9 cells have also been purified and analyzed by EM and 3D reconstruction (Ogura et al. 2006). The resultant three-dimensional structure of $\gamma$-secretase at $48 \AA$ resolution occupied a volume of $560 \times 320 \times 240 \AA$, which resembled a flattened heart comprised of two oppositely faced, dimpled domains; a low-density space containing multiple pores resided between the domains, which may house the catalytic site. The differences in the predicted shape and size of the complex between the two studies may reflect monomeric versus dimeric or oligomeric states and may stem from the distinct conditions for reconstitution, detergent extraction and purification, as well as the limitation of the resolution of the method for revealing the internal structure of $\gamma$-secretase at the atomic level.

The most intriguing aspect in the structurefunction relationship of $\gamma$-secretase is how it executes the proteolytic cleavage of the membrane-spanning segment of substrate proteins within the hydrophobic lipid bilayer. To examine the water accessibility of the regions flanking the catalytic aspartate residues in the sixth and seventh TMDs of PSEN1, the substituted cysteine accessibility method (SCAM) was applied. This involves the use of disulfide-forming reagents to probe accessibility of specific amino acids that have been changed to cysteines. Via SCAM, TMD6 and TMD7 were found to be partly facing a hydrophilic environment (i.e., in a catalytic pore structure) that enables the intramembrane proteolysis (Fig. 4A) (Sato et al. 2006; Tolia et al. 2006). Residues at the luminal portion of TMD6 are predicted to form a subsite for substrate or inhibitor binding on the $\alpha$-helix facing a hydrophilic milieu, whereas those around the GxGD catalytic motif within TMD7 are highly water accessible, suggesting formation of a hydrophilic cavity within the membrane region. The SCAM data also suggested that the two catalytic aspartates are closely opposed to each other. Subsequently, the structures of TMD 8, 9, and the carboxyl terminus of PSEN1, which are located carboxy terminally to the catalytic domain and include the conserved PAL motif and the hydrophobic carboxy-terminal tip, both of which are implicated in the formation of the $\gamma$-secretase complex and its catalytic activity, were analyzed by SCAM (Fig. 4B) (Sato et al. 2008; Tolia et al. 2008). The amino acid residues around the proline-alanine-leucine (PAL) motif and the luminal side of TMD9 were highly water accessible and located in proximity to the catalytic center. The region starting from the luminal end of TMD9 toward the carboxyl terminus formed an amphipathic $\alpha$-helix-like structure that extended along the interface between the membrane and the extracellular milieu. Competition analysis using $\gamma$-secretase inhibitors showed the involvement of TMD9 in the initial binding of substrates, as well as in the subsequent catalytic process as a subsite. Recently, TMD1 of PS1 also was shown to be involved in the hydrophilic catalytic pore, serving as a part of subsite for $\gamma$-secretase cleavage, together with TMD 6, 7, and 9 (Takagi et al. 2010).

Recently, the structure of the CTF of human PS1 was analyzed by nuclear magnetic resonance studies in SDS micelles (Sobhanifar et al. 2010). The structure revealed a topology where the membrane was likely traversed three times in accordance with the nine TMD model of PS1, but containing unique structural features adapted to accommodate intramembrane catalysis, including a putative half-membranespanning helix amino-terminally harboring the second catalytic aspartate (residue 385), a severely kinked helical structure toward the carboxyl terminus, as well as a soluble helix in the unstructured amino-terminal loop of the CTF. These predicted structures were in good accordance with those obtained by SCAM analysis.

\section{PRESENILINS AND DISEASE}

As mentioned earlier, presenilin mutations were first identified in connection with familial $\mathrm{AD}$, and subsequent work established that presenilin is the catalytic component of the $\gamma$-secretase complex that produces $A \beta$. This and other 

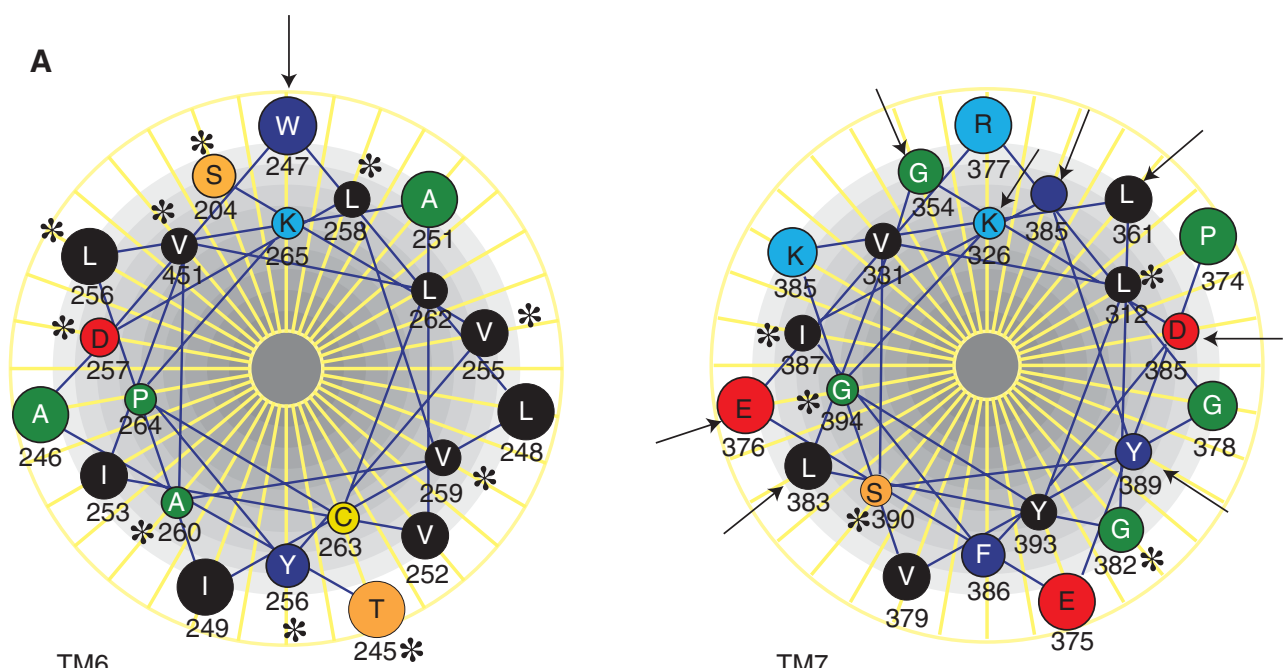

TM7

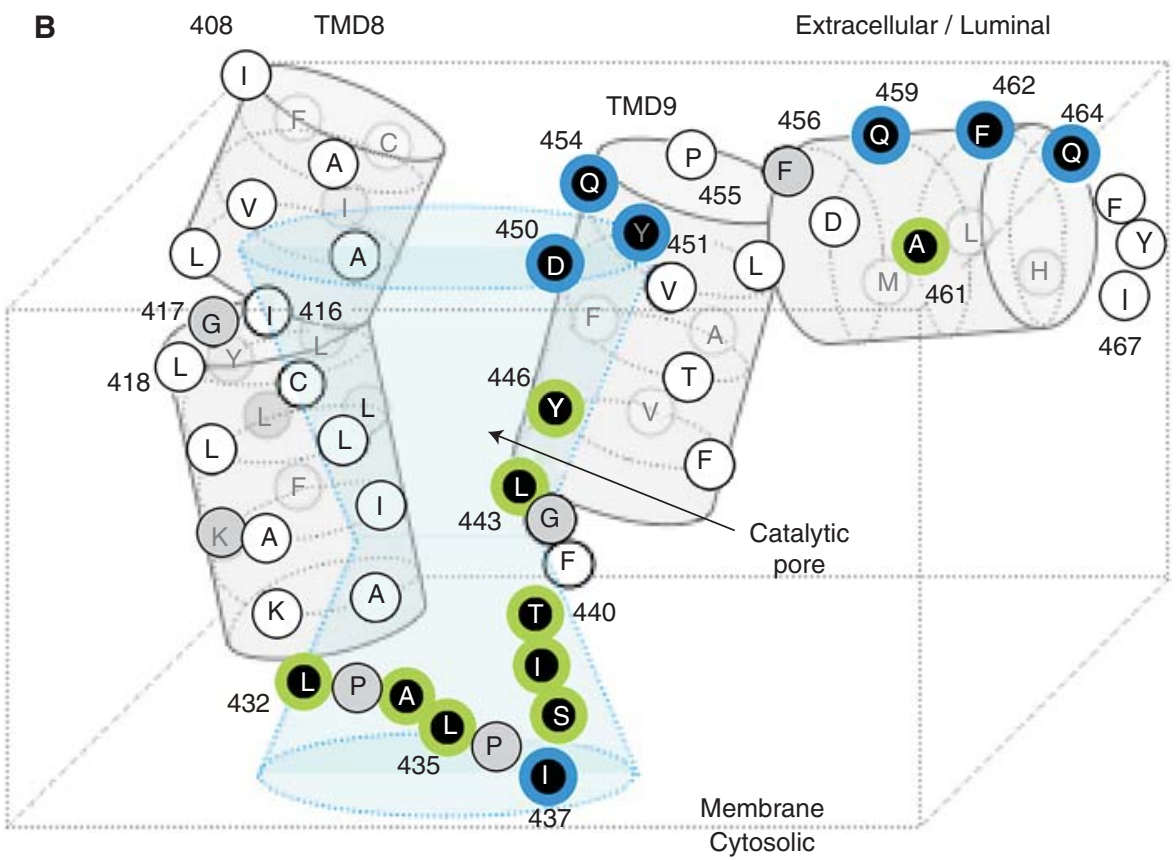

Figure 4. Predicted structure in and around the putative catalytic pore of PS1 based on the results of SCAM analysis. (A) Helical wheel model of TMD6 and 7 viewed from the amino terminus. The arrows and asterisks indicate amino acids reactive and nonreactive to biotin-HPDP, respectively, by the SCAM analysis (Tolia et al. 2006). Note that most of the accessible residues cluster on one side, although this domain does not seem to be a classically amphipathic helix. (B) Hypothetical structure around TMD8, 9, and the extreme carboxyl terminus of PS1 in relation to the catalytic pore. Residues labeled by 2-aminoethyl methanethiosulfonate (MTSEA)-biotin by the SCAM analysis (that are accessible to hydrophilic environment; Sato et al. 2008) are shown by a white letter in a black circle. 
evidence strongly implicate $A \beta$, particularly $\mathrm{A} \beta 42$, in the pathogenesis of monogenic, dominant familial $\mathrm{AD}$ cases (i.e., those with missense mutations in APP, PSEN1, or PSEN2 genes). AD-associated mutations in the presenilins alter the ratio of $A \beta 42 / A \beta 40$, a critical factor in the tendency of $A \beta$ to aggregate into neurotoxic species, whether the deleterious aggregates are fibrillar plaques or (according to current thinking) soluble oligomers (reviewed in Mucke 2011). Thus, these missense mutations alter the biochemical character of the $\gamma$-secretase complex and its interaction with the APP substrate to skew the transmembrane cleavage toward longer, more aggregation-prone forms of $A \beta$.

Interestingly, most of the $\mathrm{AD}$-associated mutations in presenilin also cause a reduction in overall proteolytic activity (Song et al. 1999; Moehlmann et al. 2002; Schroeter et al. 2003; Bentahir et al. 2006), raising the question of whether a partial loss of presenilin function causes familial AD. Indeed, conditional knockout of PSEN1 and PSEN2 in the mouse brain results in neurodegeneration and memory deficits reminiscent of $\mathrm{AD}$, albeit with no $\mathrm{A} \beta$ production (Saura et al. 2004; Wines-Samuelson et al. 2010). However, all of the mutations in the presenilins associated with $\mathrm{AD}$ (over 160 such mutations have been identified) are dominant, one mutant allele being sufficient to cause the carrier to develop $\mathrm{AD}$ in midlife. Furthermore, none of these $\mathrm{AD}$-associated mutations result in truncation or loss of the presenilin protein, and the mutant protein assembles with other $\gamma$-secretase components into full complexes that are proteolytically active (and thus compatible with entirely normal development). Complete loss-of-function mutations in PSEN1, Pen-2, and Nicastrin in humans cause familial forms of a severe skin disorder, not neurodegeneration or AD (Wang et al. 2010). Although many of the AD-mutant forms of PSEN1 lead to some reduction in proteolytic function, some mutants display only subtle reductions, if any at all (Kulic et al. 2000). Moreover, no familial AD mutations have been found in any other $\gamma$-secretase substrate besides APP, strongly suggesting that it is alteration of APP proteolysis by the mutant presenilins that is the key to the pathogenesis of $\mathrm{AD}$. Together, these observations suggest that an altered $\mathrm{A} \beta 42 / \mathrm{A} \beta 40$ ratio is the critical factor by which presenilin mutations cause familial AD. Such mutations may or may not be accompanied by a reduction of proteolytic activity, but a complete loss of activity is not observed with any of these mutations. The phenotypes observed in the conditional knockout mice may reflect an essential role of presenilins in neuronal health or function (e.g., neurotransmitter release; Zhang et al. 2009) that is only revealed on complete removal of these proteins, and deficient Notch signaling is certainly to be considered as a contributing factor in $\mathrm{AD}$ pathogenesis (Costa et al. 2003, 2005; Ge et al. 2004; Presente et al. 2004; Wang et al. 2004). Nevertheless, reduced function in certain signaling pathways may be a secondary contributing factor in the early-onset $\mathrm{AD}$ cases associated with presenilin mutations, although they cause no other known medical consequences.

Aside from onset in middle age and dominant genetic inheritance, the relatively rare familial AD cases mostly display essentially the same progression of symptoms and the same plaque and tangle pathology as late-onset sporadic $A D$. Thus, the clear involvement of $A \beta$ in familial $\mathrm{AD}$ also implicates this peptide in the pathogenesis of the much more common sporadic form of the disease. As the presenilincontaining $\gamma$-secretase complex carries out the proteolysis that determines the carboxyl terminus of $A \beta$ and the critical $A \beta 42 / A \beta 40$ ratio, the protease complex is likewise implicated in the pathogenic pathway of sporadic $\mathrm{AD}$. That being said, there is little evidence that the structure and properties of presenilin $/ \boldsymbol{\gamma}$-secretase are different in sporadic $\mathrm{AD}$ patients versus non-AD controls, or that sporadic $\mathrm{AD}$ involves specific changes in the $A \beta 42 / A \beta 40$ ratio that are produced by $\gamma$-secretase. Nevertheless, it remains possible that local cellular changes alter APP proteolysis by $\gamma$-secretase to produce longer forms of $A \beta$. For instance, environmental factors such as diet may influence membrane composition to elicit such changes. Whether or not 
Presenilins and $\gamma$-Secretase

such speculations are ultimately borne out, all $\mathrm{A} \beta$ is produced via the $\gamma$-secretase complex, which makes the protease critical to the disease process. Without $\gamma$-secretase-mediated production of $A \beta$, the disease process should not occur.

In addition to its role in $A \beta$ generation and $\mathrm{AD}$, presenilin $/ \boldsymbol{\gamma}$-secretase is an essential component of the Notch signaling pathway, as noted earlier. As Notch signaling often keeps precursor cells in a dividing, less specialized state, overactivation of this pathway can cause cancer. Indeed, mutations in Notch are implicated in various forms of cancer (Shih Ie and Wang 2007). These mutations result in a Notch protein that can signal even in the absence of its cognate protein ligand (such as Delta and Jagged). For instance, a chromosomal translocation that results in a truncated, constitutively active form of Notch1 is found in rare cases of human T-cell acute lymphoblastic leukemia (T-ALL) (Ellisen et al. 1991; Grabher et al. 2006), whereas activating point mutations in Notch1 have been found in $50 \%$ of all T-ALL (Weng et al. 2004). Elevation of Notch3 expression is implicated in subsets of non-small-cell lung cancer (Dang et al. 2000) and ovarian cancer (Park et al. 2006), and activation of Notch signaling is also implicated in breast cancer (Hu et al. 2006). For this reason, $\gamma$-secretase is considered a potential anticancer target, i.e., blocking the overactivated Notch signaling pathway by preventing the release of the Notch intracellular domain, a transcriptional activator (e.g., Tammam et al. 2009). However, some cancer-causing Notch mutations bypass $\gamma$-secretase altogether, producing a truncated form of the receptor comprised of only the intracellular domain (i.e., not membrane localized) (Pear and Aster 2004). Thus, knowledge of the specific Notch mutations in individual patients would be critical in deciding whether to use a $\gamma$-secretase inhibitor to treat cancers. In contrast, in the skin, Notch acts as a tumor suppressor, and $\gamma$-secretase inhibition can cause skin cancer by interfering with Notch signaling (Demehri et al. 2009) (see below). This further complicates the use of such inhibitors to treat other types of cancer that involve Notch overactivation.

\section{$\gamma$-SECRETASE AS A DRUG TARGET}

Because the presenilin-containing $\gamma$-secretase complex plays an essential role in producing the $A \beta$ peptide, considerable efforts have gone into the discovery and development of smallmolecule inhibitors as potential therapeutics for AD. Early inhibitors were useful chemical tools for characterizing $\gamma$-secretase as an aspartyl protease (Wolfe et al. 1999a; Shearman et al. 2000), for labeling presenilin to provide evidence that the active site resides at the interface between PS1 NTF and CTF (Esler et al. 2000; Li et al. 2000), for purification of the protease complex (Esler et al. 2002; Beher et al. 2003; Fraering et al. 2004b), and for addressing its mechanism of action (Esler et al. 2002; Kornilova et al. 2005). Most of these compounds, however, were peptidomimetics with poor druglike qualities. The development of inhibitors with better in vivo activity led to the demonstration of $A \beta$ lowering in the brains of transgenic mice overexpressing AD-associated human APP mutants (Dovey et al. 2001; Lanz et al. 2004). However, treatment over an extended period (e.g., $2 \mathrm{wk}$ ) resulted in gastrointestinal toxicity and immunosuppression, owing to interference with the Notch signaling pathway (Searfoss et al. 2003; Wong et al. 2004).

Other evidence shows that, in contrast to its role in cell proliferation in many other cell types, Notch signaling acts as a tumor suppressor in epithelia (Nicolas et al. 2003; Proweller et al. 2006; Demehri et al. 2009), and that reduction of $\gamma$-secretase components can result in skin cancers (Xia et al. 2001; Li et al. 2007). Indeed, it has become clear that compounds targeting $\gamma$-secretase for the potential treatment of AD should alter $A \beta$ production without significantly lowering the normal, physiologically regulated release of the Notch intracellular domain. The $\gamma$-secretase inhibitor that had advanced the furthest in clinical trials, LY450139 (semagacestat; Fig. 5) from Eli Lilly (Fleisher et al. 2008), displayed very little, if any, selectivity for APP compared to Notch, raising concern that doses that effectively lower brain $A \beta$ production would cause systemic toxicity owing to inhibition of Notch signaling. Indeed, a phase 3 trial 


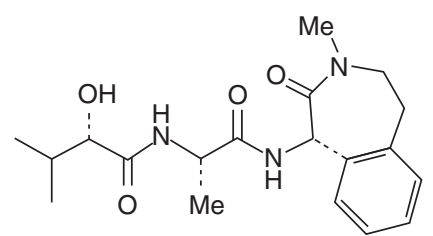

LY-450139<smiles>O=S(=O)(NC(CO)C(C(F)(F)F)C(F)(F)F)c1ccc(Cl)s1</smiles><smiles>NC(=O)C(CCC(F)(F)F)N(Cc1ccc(-c2ncon2)cc1F)S(=O)(=O)c1ccccc1</smiles>

BMS-708, 163

Figure 5. $\gamma$-Secretase inhibitors recently or currently in clinical trials for the treatment of Alzheimer disease. LY450139 shows little selectivity for APP with respect to the Notch receptor, whereas GSI-953 and BMS-708,163 are clearly selective.

of this compound was halted owing to increased incidences of skin cancer, GI side effects, and some worsening of cognitive function.

Two general classes of compounds targeting $\gamma$-secretase have been found to alter $A \beta$ production with varying degrees of selectivity with respect to Notch. The first are so-called $\gamma$-secretase modulators, which do not inhibit $\mathrm{A} \beta$ production, but instead shift production away from the more aggregation-prone $A \beta 42$ and increase formation of a more soluble 38-residue form (A 338$)$. These $\gamma$-secretase modulators are exemplified by a subset of nonsteroidal antiinflammatory drugs (NSAIDs) (such as ibuprofen and sulindac sulfide) that were the first compounds discovered to alter the $\gamma$-secretase processing of APP in this therapeutically important manner (Weggen et al. 2001). Only certain NSAIDs display this property, and in a manner that does not depend on inhibition of cyclooxygenase (the target of NSAIDs that mediates their antiinflammatory activity). The first compound in this class to enter into clinical trials, R-flurbiprofen (tarenflurbil, Flurizan), is a single enantiomer of a clinically approved racemic NSAID (Eriksen et al. 2003; Galasko et al. 2007; Kukar et al. 2007). Unlike its mirror image, R-flurbiprofen does not inhibit cyclooxygenase, but it nevertheless retains the ability to lower $A \beta 42$. This drug candidate, however, eventually failed owing to lack of efficacy (Green et al. 2009), a result that was not surprising given the very poor potency and brain penetration of this agent. Other compounds with similar properties, but that are much more potent, are in various stages of development. How these compounds elicit their effects is unclear. Some evidence suggests that the compounds selectively target the APP substrate (Kukar et al. 2008), whereas other studies suggest a direct interaction with the protease complex, even in the absence of substrate (Beher et al. 2004). The former mode of interaction (substrate targeting) would be unusual, while the latter mode (allosteric inhibition) is more common.

The second class of therapeutically promising molecules is the so-called "Notch-sparing" $\gamma$-secretase inhibitors. These compounds are capable of decreasing the proteolysis of APP by $\gamma$-secretase (and thereby decreasing the production of all forms of $A \beta$ ) while allowing the enzyme to continue processing the Notch receptor. Early compounds reported with this property were weak inhibitors identified by screening kinase inhibitors: The screen was based on the finding that the $\gamma$-secretase complex contains an ATP-binding site that affects the processing of APP but not that of Notch (Fraering et al. 2005). As kinase inhibitors typically interact with ATP-binding sites, the thought was that some kinase inhibitors might interact with an ATP-binding site on $\gamma$ secretase. The abl kinase inhibitor imatinib (Gleevec) was the first reported Notch-sparing $\gamma$-secretase inhibitor, doing so in an abl kinase-independent manner (Netzer et al. 2003). Recent affinity isolation of the imatinib target 
apparently responsible for the $A \beta$-lowering effects identified $\gamma$-secretase activating protein (GSAP), a novel $16 \mathrm{kDa}$ protein that can interact stably with the $\gamma$-secretase complex $(\mathrm{He}$ et al. 2010).

Since the identification of these initial, weak agents, a number of much more potent Notchsparing inhibitors have been reported, with several that are currently in early- to mid-stage clinical trials (Kreft et al. 2009). These include BMS-708,163 (Fig. 5) from Bristol-MyersSquibb (BMS) (Gillman et al. 2010), PF3,084,014 from Pfizer (Lanz et al. 2010), and GSI-953 (begacestat; Fig. 5) from Wyeth (now part of Pfizer) (Mayer et al. 2008). The Wyeth compound displays nanomolar potency but only 14-fold selectivity for APP over Notch, which may not be sufficient to avoid peripheral Notch-related toxicities. The BMS and Pfizer compounds are both highly potent (nanomolar to subnanomolar) and selective $(\sim 200-$ to 300 -fold); however, it is still unclear whether this selectivity will be sufficient if the compounds do not have high brain penetration.

Avoiding interference with $\gamma$-secretase proteolysis of Notch could provide compounds that will have other toxicities that had been masked by the Notch-deficient phenotypes. As mentioned earlier, $\gamma$-secretase cleaves many type I membrane proteins after ectodomain release by cell surface sheddases (Beel and Sanders 2008). In some cases, proteolysis of the substrate results in a signaling event or other specific cellular function, for example, the $\gamma$-secretase proteolysis of $\mathrm{N}$-cadherin (Marambaud et al. 2003) mentioned earlier. Also, neuregulin-1-triggered $\gamma$-secretase cleavage of ErbB4 inhibits astrocyte differentiation by interacting with repressors of astrocyte gene expression (Sardi et al. 2006). It is presently unclear whether interference with these cellular functions will result in toxicity in vivo. In other cases, however, proteolysis of a substrate by $\gamma$-secretase may not serve a specific cellular function but may simply be a means of clearing the membrane of protein stubs left behind after ectodomain shedding (Kopan and Ilagan 2004). Although this might appear to be an essential housekeeping function, no general mechanism-based cell toxicity has been observed from $\gamma$-secretase inhibitors, perhaps owing to redundant function by other membraneembedded proteases. Another important issue is selectivity with respect to the family of presenilin homologs exemplified by signal peptide peptidase (Golde et al. 2009). Such "off-target" interactions could also result in toxicity in vivo.

\section{CONCLUDING REMARKS}

Since the discovery of PSEN mutations associated with early-onset AD in 1995, our understanding of the nature of the $\gamma$-secretase complex and the normal and pathological functions of presenilins has come far. Challenges for the future include elucidating the detailed structure of this 19-TMD complex and translating our understanding into practical therapeutics for $\mathrm{AD}$. The hope is that a second edition of this collection will describe major advances on these and other research fronts, and perhaps even some success in the clinic.

\section{ACKNOWLEDGMENTS}

B.D. is Arthur Bax and Anna Vanluffelen chair for Alzheimer disease research, and is supported by a Methusalem grant from the K.U. Leuven and the Flemisch government, by the Fund for Scientific Research Flanders (FWO-V), the Foundation for Alzheimer Research (SAO/FRMA), and the Interuniversity Attraction Pole Program (IAP P6/43) of the Belgian Federal Science Policy Office. T.I. is Professor of Neuropathology and supported by the Ministry of Education, Culture, Sports, Science, and Technology, and by Core Research for Evolutional Science and Technology of Japan. M.S.W. is Professor of Neurology and is supported by grants from the National Institutes of Health, the Alzheimer's Association, and the American Health Assistance Foundation.

\section{REFERENCES}

* Reference is also in this collection.

Alzheimer's Disease Collaborative Group. 1995. The structure of the presenilin 1 (S182) gene and identification of six novel mutations in early onset AD families. Nat Genet 11: 219-222. 
B. De Strooper et al.

Baumann K, Paganetti PA, Sturchler-Pierrat C, Wong C, Hartmann H, Cescato R, Frey P, Yankner BA, Sommer B, Staufenbiel M. 1997. Distinct processing of endogenous and overexpressed recombinant presenilin 1. Neurobiol Aging 18: 181-189.

Beel AJ, Sanders CR. 2008. Substrate specificity of $\gamma$-secretase and other intramembrane proteases. Cell Mol Life Sci 65: 1311-1334.

Beher D, Fricker M, Nadin A, Clarke EE, Wrigley JD, Li YM, Culvenor JG, Masters CL, Harrison T, Shearman MS 2003. In vitro characterization of the presenilindependent $\gamma$-secretase complex using a novel affinity ligand. Biochemistry 427: 8133-8142.

Beher D, Clarke EE, Wrigley JD, Martin AC, Nadin A Churcher I, Shearman MS. 2004. Selected non-steroidal anti-inflammatory drugs and their derivatives target $\gamma$-secretase at a novel site. Evidence for an allosteric mechanism. J Biol Chem 279: 43419-43426.

Bentahir M, Nyabi O, Verhamme J, Tolia A, Horre K, Wiltfang J, Esselmann H, De Strooper B. 2006. Presenilin clinical mutations can affect $\gamma$-secretase activity by different mechanisms. J Neurochem 96: 732-742.

Bezprozvanny I, Mattson MP. 2008. Neuronal calcium mishandling and the pathogenesis of Alzheimer's disease. Trends Neurosci 31: 454-463.

Borchelt DR, Thinakaran G, Eckman CB, Lee MK, Davenport F, Ratovitsky T, Prada CM, Kim G, Seekins S, Yager D, et al. 1996. Familial Alzheimer's disease-linked presenilin 1 variants elevate $A \beta 1-42 / 1-40$ ratio in vitro and in vivo. Neuron 17: 1005-1013.

Borchelt DR, Ratovitski T, van Lare J, Lee MK, Gonzales V, Jenkins NA, Copeland NG, Price DL, Sisodia SS. 1997. Accelerated amyloid deposition in the brains of transgenic mice coexpressing mutant presenilin 1 and amyloid precursor proteins. Neuron 19: 939-945.

Capell A, Kaether C, Edbauer D, Shirotani K, Merkl S Steiner H, Haass C. 2003. Nicastrin interacts with $\gamma$-secretase complex components via the $\mathrm{N}$-terminal part of its transmembrane domain. J Biol Chem 278: 52519-52523.

Chan SL, Mayne M, Holden CP, Geiger JD, Mattson MP. 2000. Presenilin-1 mutations increase levels of ryanodine receptors and calcium release in PC12 cells and cortical neurons. J Biol Chem 275: 18195-18200.

Chen F, Hasegawa H, Schmitt-Ulms G, Kawarai T, Bohm C, Katayama T, Gu Y, Sanjo N, Glista M, Rogaeva E, et al. 2006. TMP21 is a presenilin complex component that modulates $\gamma$-secretase but not $\varepsilon$-secretase activity. Nature 440: $1208-1212$.

Cheung KH, Shineman D, Muller M, Cardenas C, Mei L, Yang J, Tomita T, Iwatsubo T, Lee VM, Foskett JK. 2008. Mechanism of $\mathrm{Ca}^{2+}$ disruption in Alzheimer's disease by presenilin regulation of Ins $\mathrm{P} 3$ receptor channel gating. Neuron 58: $871-883$.

Chiang PM, Fortna RR, Price DL, Li T, Wong PC. 2010. Specific domains in anterior pharynx-defective 1 determine its intramembrane interactions with nicastrin and presenilin. Neurobiol Aging doi: 10.1016/j.neurobiolaging. 2009.12.028.

Citron M, Westaway D, Xia W, Carlson G, Diehl T, Levesque G, Johnson-Wood K, Lee M, Seubert P, Davis A, et al. 1997. Mutant presenilins of Alzheimer's disease increase production of 42-residue amyloid $\beta$-protein in both transfected cells and transgenic mice. Nat Med 3: 67-72.

Costa RM, Honjo T, Silva AJ. 2003. Learning and memory deficits in Notch mutant mice. Curr Biol 13: 1348-1354.

Costa RM, Drew C, Silva AJ. 2005. Notch to remember. Trends Neurosci 28: 429-435.

Crystal AS, Morais VA, Pierson TC, Pijak DS, Carlin D, Lee VM, Doms RW. 2003. Membrane topology of $\gamma$-secretase component PEN-2. J Biol Chem 278: 20117-20123.

Dang TP, Gazdar AF, Virmani AK, Sepetavec T, Hande KR, Minna JD, Roberts JR, Carbone DP. 2000. Chromosome 19 translocation, overexpression of Notch3, and human lung cancer. J Natl Cancer Inst 92: 1355-1357.

Dejaegere T, Serneels L, Schafer MK, Van Biervliet J, Horre K, Depboylu C, Alvarez-Fischer D, Herreman A, Willem M, Haass C, et al. 2008. Deficiency of Aph1B/C- $\gamma$-secretase disturbs Nrg1 cleavage and sensorimotor gating that can be reversed with antipsychotic treatment. Proc Natl Acad Sci 105: 9775-9780.

Demehri S, Turkoz A, Kopan R. 2009. Epidermal Notch1 loss promotes skin tumorigenesis by impacting the stromal microenvironment. Cancer Cell 16: 55-66.

De Strooper B. 2003. Aph-1, Pen-2, and nicastrin with presenilin generate an active $\gamma$-secretase complex. Neuron 38: $9-12$.

De Strooper B, Saftig P, Craessaerts K, Vanderstichele H, Guhde G, Annaert W, Von Figura K, Van Leuven F. 1998. Deficiency of presenilin-1 inhibits the normal cleavage of amyloid precursor protein. Nature 391: 387-390.

De Strooper B, Annaert W, Cupers P, Saftig P, Craessaerts K, Mumm JS, Schroeter EH, Schrijvers V, Wolfe MS, Ray WJ, et al. 1999. A presenilin-1-dependent $\gamma$-secretase-like protease mediates release of Notch intracellular domain. Nature 398: 518-522.

Doan A, Thinakaran G, Borchelt DR, Slunt HH, Ratovitsky T, Podlisny M, Selkoe DJ, Seeger M, Gand SE, Price DL, et al. 1996. Protein topology of presenilin 1. Neuron 17: 1023-1030.

Doerfler P, Shearman MS, Perlmutter RM. 2001. Presenilindependent $\gamma$-secretase activity modulates thymocyte development. Proc Natl Acad Sci 98: 9312-9317.

Dovey HF, John V, Anderson JP, Chen LZ, de Saint Andrieu P, Fang LY, Freedman SB, Folmer B, Goldbach E, Holsztynska EJ, et al. 2001. Functional $\gamma$-secretase inhibitors reduce $\beta$-amyloid peptide levels in brain. J Neurochem 76: $173-181$.

Duff K, Eckman C, Zehr C, Yu X, Prada CM, Perez-tur J, Hutton M, Buee L, Harigaya Y, Yager D, et al. 1996. Increased amyloid- $\beta 42(43)$ in brains of mice expressing mutant presenilin 1. Nature 383: 710-713.

Edbauer D, Winkler E, Regula JT, Pesold B, Steiner H, Haass C. 2003. Reconstitution of $\gamma$-secretase activity. Nat Cell Biol 5: 486-488.

Eggert S, Paliga K, Soba P, Evin G, Masters CL, Weidemann A, Beyreuther K. 2004. The proteolytic processing of the amyloid precursor protein gene family members APLP-1 and APLP-2 involves $\alpha-, \beta-, \gamma-$, and $\varepsilon$-like cleavages: Modulation of APLP-1 processing by $n$-glycosylation. J Biol Chem 279: 18146-18156. 
Ellisen LW, Bird J, West DC, Soreng AL, Reynolds TC, Smith SD, Sklar J. 1991. TAN-1, the human homolog of the Drosophila notch gene, is broken by chromosomal translocations in T lymphoblastic neoplasms. Cell 66: 649-661.

Eriksen JL, Sagi SA, Smith TE, Weggen S, Das P, McLendon DC, Ozols VV, Jessing KW, Zavitz KH, Koo EH, et al. 2003. NSAIDs and enantiomers of flurbiprofen target $\gamma$-secretase and lower $A \beta 42$ in vivo. J Clin Invest 112: $440-449$.

Esler WP, Kimberly WT, Ostaszewski BL, Diehl TS, Moore CL, Tsai J-Y, Rahmati T, Xia W, Selkoe DJ, Wolfe MS 2000. Transition-state analogue inhibitors of $\gamma$-secretase bind directly to presenilin-1. Nature Cell Biol 2: 428-434.

Esler WP, Kimberly WT, Ostaszewski BL, Ye W, Diehl TS, Selkoe DJ, Wolfe MS. 2002. Activity-dependent isolation of the presenilin $/ \gamma$-secretase complex reveals nicastrin and a $\gamma$ substrate. Proc Natl Acad Sci 99: 2720-2725.

Esselens C, Oorschot V, Baert V, Raemaekers T, Spittaels K, Serneels L, Zheng H, Saftig P, De Strooper B, Klumperman J, et al. 2004. Presenilin 1 mediates the turnover of telencephalin in hippocampal neurons via an autophagic degradative pathway. J Cell Biol 166: 1041-1054.

Fleisher AS, Raman R, Siemers ER, Becerra L, Clark CM, Dean RA, Farlow MR, Galvin JE, Peskind ER, Quinn JF et al. 2008. Phase 2 safety trial targeting amyloid $\beta$ production with a $\gamma$-secretase inhibitor in Alzheimer disease. Arch Neurol 65: 1031-1038.

Flood DG, Reaume AG, Dorfman KS, Lin YG, Lang DM, Trusko SP, Savage MJ, Annaert WG, De Strooper B, Siman R, et al. 2002. FAD mutant PS-1 gene-targeted mice: Increased $A \beta 42$ and $A \beta$ deposition without APP overproduction. Neurobiol Aging 23: 335-348.

Fortna RR, Crystal AS, Morais VA, Pijak DS, Lee VM, Doms RW. 2004. Membrane topology and nicastrin-enhanced endoproteolysis of APH-1, a component of the $\gamma$-secretase complex. J Biol Chem 279: 3685-3693.

Fraering PC, LaVoie MJ, Ye W, Ostaszewski BL, Kimberly WT, Selkoe DJ, Wolfe MS. 2004a. Detergent-dependent dissociation of active $\gamma$-secretase reveals an interaction between Pen-2 and PS1-NTF and offers a model for subunit organization within the complex. Biochemistry 43: 323-333.

Fraering PC, Ye W, Strub JM, Dolios G, LaVoie MJ, Ostaszewski BL, Van Dorsselaer A, Wang R, Selkoe DJ, Wolfe MS. 2004b. Purification and characterization of the human $\gamma$-Secretase complex. Biochemistry 43: $9774-$ 9789.

Fraering PC, Ye W, Lavoie MJ, Ostaszewski BL, Selkoe DJ, Wolfe MS. 2005. $\gamma$-Secretase substrate selectivity can be modulated directly via interaction with a nucleotide binding site. J Biol Chem 280: 41987-41996.

Francis R, McGrath G, Zhang J, Ruddy DA, Sym M, Apfeld J, Nicoll M, Maxwell M, Hai B, Ellis MC, et al. 2002. aph-1 and pen-2 are required for Notch pathway signaling, $\gamma$-secretase cleavage of $\beta$ APP, and presenilin protein accumulation. Dev Cell 3: 85-97.

Fukumori A, Fluhrer R, Steiner H, Haass C. 2010. Threeamino acid spacing of presenilin endoproteolysis suggests a general stepwise cleavage of $\gamma$-secretase-mediated intramembrane proteolysis. J Neurosci 30: 7853-7862.

Galasko DR, Graff-Radford N, May S, Hendrix S, Cottrell BA, Sagi SA, Mather G, Laughlin M, Zavitz KH, Swabb
E, et al. 2007. Safety, tolerability, pharmacokinetics, and $\mathrm{A} \beta$ levels after short-term administration of R-flurbiprofen in healthy elderly individuals. Alzheimer Dis Assoc Disord 21: 292-299.

Ge X, Hannan F, Xie Z, Feng C, Tully T, Zhou H, Xie Z, Zhong Y. 2004. Notch signaling in Drosophila long-term memory formation. Proc Natl Acad Sci 101: 1017210176.

Georgakopoulos A, Marambaud P, Efthimiopoulos S, Shioi J, Cui W, Li HC, Schutte M, Gordon R, Holstein GR, Martinelli G, et al. 1999. Presenilin-1 forms complexes with the cadherin/catenin cell-cell adhesion system and is recruited to intercellular and synaptic contacts. Mol Cell 4: 893-902.

Gillman KW, Starrett JE, Parker MF, Xie K, Bronson JJ, Marcin LR, McElhone KE, Bergstrom CP, Mate RA, Williams R, et al. 2010. Discovery and evaluation of BMS-708163, a potent, selective and orally bioavailable $\gamma$-secretase inhibitor. ACS Med Chem Lett 1: 120-124.

Golde TE, Wolfe MS, Greenbaum DC. 2009. Signal peptide peptidases: A family of intramembrane-cleaving proteases that cleave type 2 transmembrane proteins. Semin Cell Dev Biol 20: 225-230.

Goutte C, Hepler W, Mickey KM, Priess JR. 2000. aph-2 encodes a novel extracellular protein required for GLP-1 mediated signaling. Development 127: 2481-2492.

Goutte C, Tsunozaki M, Hale VA, Priess JR. 2002. APH-1 is a multipass membrane protein essential for the Notch signaling pathway in Caenorhabditis elegans embryos. Proc Natl Acad Sci 99: 775-779.

Grabher C, von Boehmer H, Look AT. 2006. Notch 1 activation in the molecular pathogenesis of T-cell acute lymphoblastic leukaemia. Nat Rev Cancer 6: 347-359.

Green KN, Demuro A, Akbari Y, Hitt BD, Smith IF, Parker I, LaFerla FM. 2008. SERCA pump activity is physiologically regulated by presenilin and regulates amyloid- $\beta$ production. J Cell Biol 181: 1107-1116.

Green RC, Schneider LS, Amato DA, Beelen AP, Wilcock G, Swabb EA, Zavitz ZH. 2009. Effect of tarenflurbil on cognitive decline and activities of daily living in patients with mild Alzheimer disease: A randomized controlled trial. JAMA 302: 2557-2564.

Gu Y, Chen F, Sanjo N, Kawarai T, Hasegawa H, Duthie M, Li W, Ruan X, Luthra A, Mount HT, et al. 2003. APH-1 interacts with mature and immature forms of presenilins and nicastrin and may play a role in maturation of presenilin.nicastrin complexes. J Biol Chem 278: 7374-7380.

Haass C, Selkoe DJ. 1993. Cellular processing of $\beta$-amyloid precursor protein and the genesis of amyloid $\beta$-peptide. Cell 75: 1039-1042.

Haass C, Selkoe DJ. 1998. Alzheimer's disease. A technical KO of amyloid- $\beta$ peptide. Nature 391: 339-340.

* Haass C, Kaether C, Sisodia S, Thinakaran G. 2011. Trafficking and proteolytic processing of APP. Cold Spring Harb Perspect Med doi: 10.1101/cshperspect.a006270.

Hadland BK, Manley NR, Su D, Longmore GD, Moore CL, Wolfe MS, Schroeter EH, Kopan R. 2001. $\gamma$-secretase inhibitors repress thymocyte development. Proc Natl Acad Sci 98: 7487-7491.

Hayrapetyan V, Rybalchenko V, Rybalchenko N, Koulen P. 2008. The N-terminus of presenilin-2 increases single 
B. De Strooper et al.

channel activity of brain ryanodine receptors through direct protein-protein interaction. Cell Calcium 44: 507-518.

He G, Luo W, Li P, Remmers C, Netzer WJ, Hendrick J, Bettayeb K, Flajolet M, Gorelick F, Wennogle LP, et al. 2010. $\gamma$-secretase activating protein is a therapeutic target for Alzheimer's disease. Nature 467: 95-98.

Hemming ML, Elias JE, Gygi SP, Selkoe DJ. 2008. Proteomic profiling of $\gamma$-secretase substrates and mapping of substrate requirements. PLoS Biol 6: e257.

Hu C, Dievart A, Lupien M, Calvo E, Tremblay G, Jolicoeur P. 2006. Overexpression of activated murine Notch1 and Notch3 in transgenic mice blocks mammary gland development and induces mammary tumors. Am J Pathol 168: 973-990.

Kaether C, Capell A, Edbauer D, Winkler E, Novak B, Steiner H, Haass C. 2004. The presenilin C-terminus is required for ER-retention, nicastrin-binding and $\gamma$-secretase activity. Embo J 23: 4738-4748.

Kasri NN, Kocks SL, Verbert L, Hebert SS, Callewaert G, Parys JB, Missiaen L, De Smedt H. 2006. Up-regulation of inositol 1,4,5-trisphosphate receptor type 1 is responsible for a decreased endoplasmic-reticulum $\mathrm{Ca}^{2+}$ content in presenilin double knock-out cells. Cell Calcium 40: $41-51$.

Khandelwal A, Chandu D, Roe CM, Kopan R, Quatrano RS. 2007. Moonlighting activity of presenilin in plants is independent of $\gamma$-secretase and evolutionarily conserved. Proc Natl Acad Sci 104: 13337-13342.

Kim SH, Sisodia SS. 2005. Evidence that the "NF" motif in transmembrane domain 4 of presenilin 1 is critical for binding with PEN-2. J Biol Chem 280: 41953-41966.

Kimberly WT, LaVoie MJ, Ostaszewski BL, Ye W, Wolfe MS, Selkoe DJ. 2003. $\gamma$-Secretase is a membrane protein complex comprised of presenilin, nicastrin, aph-1, and pen-2. Proc Natl Acad Sci 100: 6382-6387.

Kopan R, Ilagan MX. 2004. $\gamma$-Secretase: Proteasome of the membrane? Nat Rev Mol Cell Biol 5: 499-504.

Kornilova AY, Bihel F, Das C, Wolfe MS. 2005. The initial substrate binding site of $\gamma$-secretase is located on presenilin near the active site. Proc Natl Acad Sci 102: 32303235.

Kreft AF, Martone R, Porte A. 2009. Recent advances in the identification of $\gamma$-secretase inhibitors to clinically test the $\mathrm{A} \beta$ oligomer hypothesis of Alzheimer's disease. $J$ Med Chem 52: 6169-6188.

Kukar T, Prescott S, Eriksen JL, Holloway V, Murphy MP, Koo EH, Golde TE, Nicolle MM. 2007. Chronic administration of R-flurbiprofen attenuates learning impairments in transgenic amyloid precursor protein mice. BMC Neurosci 8: 54

Kukar TL, Ladd TB, Bann MA, Fraering PC, Narlawar R, Maharvi GM, Healy B, Chapman R, Welzel AT, Price RW, et al. 2008. Substrate-targeting $\gamma$-secretase modulators. Nature 453: 925-929.

Kulic L, Walter J, Multhaup G, Teplow DB, Baumeister R, Romig H, Capell A, Steiner H, Haass C. 2000. Separation of presenilin function in amyloid $\beta$-peptide generation and endoproteolysis of Notch. Proc Natl Acad Sci 97: 5913-5918.
Lanz TA, Hosley JD, Adams WJ, Merchant KM. 2004. Studies of $A \beta$ pharmacodynamics in the brain, cerebrospinal fluid, and plasma in young (plaque-free) Tg2576 mice using the $\gamma$-secretase inhibitor N2-[(2S)-2-(3,5difluorophenyl)-2-hydroxyethanoyl]-N1-[(7S)-5-methyl6-oxo-6,7-di hydro-5H-dibenzo[b,d]azepin-7-yl]-Lalaninamide (LY-411575). J Pharmacol Exp Ther 309: 49-55.

Lanz TA, Wood KM, Richter KE, Nolan CE, Becker SL, Pozdnyakov N, Martin BA, Du P, Oborski CE, Wood DE, et al. 2010. Pharmacodynamics and pharmacokinetics of the $\gamma$-secretase inhibitor, PF-3084014. J Pharmacol Exp Ther 334: 269-277.

Laudon H, Hansson EM, Melen K, Bergman A, Farmery MR, Winblad B, Lendahl U, von Heijne G, Naslund J. 2005. A nine-transmembrane domain topology for presenilin 1. J Biol Chem 280: 35352-35360.

LaVoie MJ, Fraering PC, Ostaszewski BL, Ye W, Kimberly WT, Wolfe MS, Selkoe DJ. 2003. Assembly of the $\gamma$-secretase complex involves early formation of an intermediate subcomplex of Aph-1 and nicastrin. J Biol Chem 278: 37213-37222.

Lazarov VK, Fraering PC, Ye W, Wolfe MS, Selkoe DJ, Li H. 2006. Electron microscopic structure of purified, active $\gamma$-secretase reveals an aqueous intramembrane chamber and two pores. Proc Natl Acad Sci 103: 6889-6894.

Lee JH, Yu WH, Kumar A, Lee S, Mohan PS, Peterhoff CM, Wolfe DM, Martinez-Vicente M, Massey AC, Sovak G, et al. 2010. Lysosomal proteolysis and autophagy require presenilin 1 and are disrupted by Alzheimer-related PS1 mutations. Cell 141: 1146-1158.

Leissring MA, Paul BA, Parker I, Cotman CW, LaFerla FM. 1999. Alzheimer's presenilin-1 mutation potentiates inositol 1,4,5-trisphosphate-mediated calcium signaling in Xenopus oocytes. J Neurochem 72: 1061-1068.

Levitan D, Greenwald I. 1995. Facilitation of lin-12-mediated signalling by sel-12, a Caenorhabditis elegans S182 Alzheimer's disease gene. Nature 377: 351-354.

Levitan D, Yu G, St George Hyslop P, Goutte C. 2001. APH$2 /$ nicastrin functions in LIN-12/Notch signaling in the Caenorhabditis elegans somatic gonad. Dev Biol 240: 654-661.

Levy-Lahad E, Wasco W, Poorkaj P, Romano DM, Oshima J, Pettingell WH, Yu CE, Jondro PS, Schmidt SD, Wang K, et al. 1995. Candidate gene for the chromosome 1 familial Alzheimer's disease locus. Science 269: 973-977.

Li YM, Xu M, Lai MT, Huang Q, Castro JL, DiMuzio-Mower J, Harrison T, Lellis C, Nadin A, Neduvelil JG, et al. 2000. Photoactivated $\gamma$-secretase inhibitors directed to the active site covalently label presenilin 1 . Nature 405: 689694.

Li T, Wen H, Brayton C, Das P, Smithson LA, Fauq A, Fan X, Crain BJ, Price DL, Golde TE, et al. 2007. Epidermal growth factor receptor and notch pathways participate in the tumor suppressor function of $\gamma$-secretase. J Biol Chem 282: 32264-32273.

Ma G, Li T, Price DL, Wong PC. 2005. APH-1a is the principal mammalian APH-1 isoform present in $\gamma$-secretase complexes during embryonic development. J Neurosci 25: $192-198$.

Marambaud P, Shioi J, Serban G, Georgakopoulos A, Sarner S, Nagy V, Baki L, Wen P, Efthimiopoulos S, Shao Z, et al. 
2002. A presenilin- $1 / \gamma$-secretase cleavage releases the E-cadherin intracellular domain and regulates disassembly of adherens junctions. Embo J 21: 1948-1956.

Marambaud P, Wen PG, Dutt A, Shioi J, Takashima A, Siman R, Robakis NK. 2003. A CBP binding transcriptional repressor produced by the PS $1 / \varepsilon$-cleavage of $\mathrm{N}$-cadherin is inhibited by PS1 FAD mutations. Cell 114: 635-645.

Mayer SC, Kreft AF, Harrison B, Abou-Gharbia M, Antane M, Aschmies S, Atchison K, Chlenov M, Cole DC, Comery T, et al. 2008. Discovery of begacestat, a Notch-1sparing $\gamma$-secretase inhibitor for the treatment of Alzheimer's disease. J Med Chem 51: 7348-7351.

McCarthy JV, Twomey C, Wujek P. 2009. Presenilin-dependent regulated intramembrane proteolysis and $\gamma$-secretase activity. Cell Mol Life Sci 66: 1534-1555.

Moehlmann T, Winkler E, Xia X, Edbauer D, Murrell J, Capell A, Kaether C, Zheng H, Ghetti B, Haass C, et al. 2002. Presenilin-1 mutations of leucine 166 equally affect the generation of the Notch and APP intracellular domains independent of their effect on $A \beta 42$ production. Proc Natl Acad Sci 99: 8025-8030.

* Mucke L. 2011. Neurotoxicity of amyloid $\beta$-protein: Synaptic and network dysfunction. Cold Spring Harb Perspect Med doi: 10.1101/cshperspect.a006338.

* Müller UC, Zheng H. 2011. Physiological functions of APP family proteins. Cold Spring Harb Perspect Med doi: 10. 1101 /cshperspect.a006288.

Naruse S, Thinakaran G, Luo JJ, Kusiak JW, Tomita T, Iwatsubo T, Qian X, Ginty DD, Price DL, Borchelt DR, et al. 1998. Effects of PS1 deficiency on membrane protein trafficking in neurons. Neuron 21: 1213-1221.

Nelson O, Tu H, Lei T, Bentahir M, de Strooper B, Bezprozvanny I. 2007. Familial Alzheimer disease-linked mutations specifically disrupt $\mathrm{Ca}^{2+}$ leak function of presenilin 1. J Clin Invest 117: 1230-1239.

Netzer WJ, Dou F, Cai D, Veach D, Jean S, Li Y, Bornmann WG, Clarkson B, Xu H, Greengard P. 2003. Gleevec inhibits $\beta$-amyloid production but not Notch cleavage. Proc Natl Acad Sci 100: 12444-12449.

Nicolas M, Wolfer A, Raj K, Kummer JA, Mill P, van Noort M, Hui CC, Clevers H, Dotto GP, Radtke F. 2003. Notch1 functions as a tumor suppressor in mouse skin. Nat Genet 33: $416-441$.

Nyabi O, Bentahir M, Horre K, Herreman A, GottardiLittell N, Van Broeckhoven C, Merchiers P, Spittaels K, Annaert W, De Strooper B. 2003. Presenilins mutated at Asp-257 or Asp-385 restore Pen-2 expression and Nicastrin glycosylation but remain catalytically inactive in the absence of wild type Presenilin. J Biol Chem 278: 43430-43436.

Ogura T, Mio K, Hayashi I, Miyashita H, Fukuda R, Kopan R, Kodama T, Hamakubo T, Iwatsubo T, Tomita T, et al. 2006. Three-dimensional structure of the $\gamma$-secretase complex. Biochem Biophys Res Commun 343: 525-534.

Osenkowski P, Li H, Ye W, Li D, Aeschbach L, Fraering PC, Wolfe MS, Selkoe DJ, Li H. 2009. Cryoelectron microscopy structure of purified $\gamma$-secretase at 12 A resolution. $J$ Mol Biol 385: 642-652.

Pardossi-Piquard R, Yang SP, Kanemoto S, Gu Y, Chen F, Bohm C, Sevalle J, Li T, Wong PC, Checler F, et al. 2009. APH1 polar transmembrane residues regulate the assembly and activity of presenilin complexes. $J$ Biol Chem 284: 16298-16307.

Park JT, Li M, Nakayama K, Mao TL, Davidson B, Zhang Z, Kurman RJ, Eberhart CG, Shih Ie M, Wang TL. 2006. Notch3 gene amplification in ovarian cancer. Cancer Res 66: 6312-6318.

Pear WS, Aster JC. 2004. T cell acute lymphoblastic leukemia/lymphoma: A human cancer commonly associated with aberrant NOTCH1 signaling. Curr Opin Hematol 11: $426-433$.

Ponting CP, Hutton M, Nyborg A, Baker M, Jansen K, Golde TE. 2002. Identification of a novel family of presenilin homologues. Hum Mol Genet 11: 1037-1044.

Presente A, Boyles RS, Serway CN, de Belle JS, Andres AJ. 2004. Notch is required for long-term memory in Drosophila. Proc Natl Acad Sci 101: 1764-1768.

Proweller A, Tu L, Lepore JJ, Cheng L, Lu MM, Seykora J, Millar SE, Pear WS, Parmacek MS. 2006. Impaired notch signaling promotes de novo squamous cell carcinoma formation. Cancer Res 66: 7438-7444.

Qyang Y, Chambers SM, Wang P, Xia X, Chen X, Goodell MA, Zheng H. 2004. Myeloproliferative disease in mice with reduced presenilin gene dosage: Effect of $\gamma$-secretase blockage. Biochemistry 43: 5352-5359.

Reinhard C, Hebert SS, De Strooper B. 2005. The amyloid- $\beta$ precursor protein: Integrating structure with biological function. EMBO J 24: 3996-4006.

Repetto E, Yoon IS, Zheng H, Kang DE. 2007. Presenilin 1 regulates epidermal growth factor receptor turnover and signaling in the endosomal-lysosomal pathway. J Biol Chem 282: 31504-31516.

Rogaev EI, Sherrington R, Rogaeva EA, Levesque G, Ikeda M, Liang Y, Chi H, Lin C, Holman K, Tsuda T, et al. 1995. Familial Alzheimer's disease in kindreds with missense mutations in a gene on chromosome 1 related to the Alzheimer's disease type 3 gene. Nature 376: 775-778.

Sardi SP, Murtie J, Koirala S, Patten BA, Corfas G. 2006. Presenilin-dependent ErbB4 nuclear signaling regulates the timing of astrogenesis in the developing brain. Cell 127: $185-197$.

Sato C, Morohashi Y, Tomita T, Iwatsubo T. 2006. Structure of the catalytic pore of $\gamma$-secretase probed by the accessibility of substituted cysteines. J Neurosci 26: $12081-$ 12088.

Sato T, Diehl TS, Narayanan S, Funamoto S, Ihara Y, De Strooper B, Steiner H, Haass C, Wolfe MS. 2007. Active $\gamma$-secretase complexes contain only one of each component. J Biol Chem 282: 33985-33993.

Sato C, Takagi S, Tomita T, Iwatsubo T. 2008. The C-terminal PAL motif and transmembrane domain 9 of presenilin 1 are involved in the formation of the catalytic pore of the $\gamma$-secretase. J Neurosci 28: 6264-6271.

Saura CA, Choi SY, Beglopoulos V, Malkani S, Zhang D, Shankaranarayana Rao BS, Chattarji SRS, Kelleher RJ III, Kandel ER, Duff K, et al. 2004. Loss of presenilin function causes impairments of memory and synaptic plasticity followed by age-dependent neurodegeneration. Neuron 42: 23-36.

Savonenko AV, Melnikova T, Laird FM, Stewart KA, Price DL, Wong PC. 2008. Alteration of BACE1-dependent NRG1/ErbB4 signaling and schizophrenia-like pheno- 
B. De Strooper et al.

types in BACE1-null mice. Proc Natl Acad Sci 105: 55855590.

Scheinfeld MH, Ghersi E, Laky K, Fowlkes BJ, D’Adamio L. 2002. Processing of $\beta$-amyloid precursor-like protein-1 and -2 by $\gamma$-secretase regulates transcription. J Biol Chem 277: 44195-44201.

Scheuner D, Eckman C, Jensen M, Song X, Citron M, Suzuki N, Bird TD, Hardy J, Hutton M, Kukull W, et al. 1996. Secreted amyloid $\beta$-protein similar to that in the senile plaques of Alzheimer's disease is increased in vivo by the presenilin 1 and 2 and APP mutations linked to familial Alzheimer's disease. Nat Med 2: 864-870.

Schroeter EH, Ilagan MX, Brunkan AL, Hecimovic S, Li YM, Xu M, Lewis HD, Saxena MT, De Strooper D, Coonrod A, et al. 2003. A presenilin dimer at the core of the $\gamma$-secretase enzyme: Insights from parallel analysis of Notch 1 and APP proteolysis. Proc Natl Acad Sci 100: 1307513080.

Searfoss GH, Jordan WH, Calligaro DO, Galbreath EJ, Schirtzinger LM, Berridge BR, Gao H, Higgins MA, May PC, Ryan TP. 2003. Adipsin: A biomarker of gastrointestinal toxicity mediated by a functional $\gamma$ secretase inhibitor. J Biol Chem 278: 46107-46116.

Serneels L, Dejaegere T, Craessaerts K, Horre K, Jorissen E, Tousseyn T, Hebert S, Coolen M, Martens G, Zwijsen A, et al. 2005. Differential contribution of the three Aph1 genes to $\gamma$-secretase activity in vivo. Proc Natl Acad Sci 102: 1719-1724.

Serneels L, Van Biervliet J, Craessaerts K, Dejaegere T, Horre K, Van Houtvin T, Esselmann H, Paul S, Schafer MK, Berezovska O, et al. 2009. $\gamma$-Secretase heterogeneity in the Aph1 subunit: Relevance for Alzheimer's disease. Science 324: 639-642.

Shearman MS, Beher D, Clarke EE, Lewis HD, Harrison T, Hunt P, Nadin A, Smith AL, Stevenson G, Castro JL. 2000. L-685,458, an aspartyl protease transition state mimic, is a potent inhibitor of amyloid $\beta$-protein precursor $\gamma$-secretase activity. Biochemistry 39: 8698-8704.

Shen J, Kelleher RJ III. 2007. The presenilin hypothesis of Alzheimer's disease: Evidence for a loss-of-function pathogenic mechanism. Proc Natl Acad Sci 104: 403-409.

Sherrington R, Rogaev EI, Liang Y, Rogaeva EA, Levesque G, Ikeda M, Chi H, Lin C, Li G, Holman K, et al. 1995. Cloning of a gene bearing missense mutations in early-onset familial Alzheimer's disease. Nature 375: 754-760.

Shih Ie M, Wang TL. 2007. Notch signaling, $\gamma$-secretase inhibitors, and cancer therapy. Cancer Res 67: 18791882.

Shirotani K, Edbauer D, Capell A, Schmitz J, Steiner H, Haass C. 2003. $\gamma$-Secretase activity is associated with a conformational change of nicastrin. J Biol Chem 278: 16474-16477.

Siman R, Reaume AG, Savage MJ, Trusko S, Lin YG, Scott RW, Flood DG. 2000. Presenilin-1 P264L knock-in mutation: Differential effects on $\mathrm{A} \beta$ production, amyloid deposition, and neuronal vulnerability. J Neurosci 20: 8717-8726.

Sobhanifar S, Schneider B, Lohr F, Gottstein F, Ikeya T, Mlynarczyk K, Pulawski W, Ghoshdastider U, Kolinski M, Filipek S, et al. 2010. Structural investigation of the Cterminal catalytic fragment of presenilin 1. Proc Natl Acad Sci 107: 9644-9649.
Song W, Nadeau P, Yuan M, Yang X, Shen J, Yankner BA. 1999. Proteolytic release and nuclear translocation of Notch-1 are induced by presenilin-1 and impaired by pathogenic presenilin-1 mutations. Proc Natl Acad Sci 96: 6959-6963.

Spasic D, Tolia A, Dillen K, Baert V, De Strooper B, Vrijens S, Annaert W. 2006. Presenilin-1 maintains a nine-transmembrane topology throughout the secretory pathway. J Biol Chem 281: 26569-26577.

Stefansson H, Sigurdsson E, Steinthorsdottir V, Bjornsdottir S, Sigmundsson T, Ghosh S, Brynjolfsson J, Gunnarsdottir S, Ivarsson O, Chou TT, et al. 2002. Neuregulin 1 and susceptibility to schizophrenia. Am J Hum Genet 71: 877-892.

Steiner H, Kostka M, Romig H, Basset G, Pesold B, Hardy JA, Capell A, Meyn L, Grim MG, Baumeister R, et al. 2000. Glycine 384 is required for presenilin-1 function and is conserved in bacterial polytopic aspartyl proteases. Nature Cell Biol 2: 848-851.

Steiner H, Winkler E, Haass C. 2008. Chemical crosslinking provides a model of the $\gamma$-secretase complex subunit architecture and evidence for close proximity of the C-terminal fragment of presenilin with APH-1. J Biol Chem 283: 34677-34686.

Struhl G, Greenwald I. 1999. Presenilin is required for activity and nuclear access of Notch in Drosophila. Nature 398: 522-525.

Takagi S, Tominaga A, Sato C, Tomita T, Iwatsubo T. 2010. Participation of transmembrane domain 1 of presenilin 1 in the catalytic pore structure of the $\gamma$-secretase. J Neurosci 30: 15943-15950.

Takasugi N, Tomita T, Hayashi I, Tsuruoka M, Niimura M, Takahashi Y, Thinakaran G, Iwatsubo T. 2003. The role of presenilin cofactors in the $\gamma$-secretase complex. Nature 422: $438-441$.

Tammam J, Ware C, Efferson C, O'Neil J, Rao S, Qu X, Gorenstein J, Angagaw M, Kim H, Kenific C, et al. 2009. Down-regulation of the Notch pathway mediated by a $\gamma$-secretase inhibitor induces anti-tumour effects in mouse models of T-cell leukaemia. Br J Pharmacol 158: 1183-1195.

Teranishi Y, Hur JY, Welander H, Franberg J, Aoki M, Winblad B, Frykman S, Tjernberg LO. 2009. Affinity pulldown of $\gamma$-secretase and associated proteins from human and rat brain. J Cell Mol Med 14: 2675-2686.

Thinakaran G, Borchelt DR, Lee MK, Slunt HH, Spitzer L, Kim G, Ratovitsky T, Davenport F, Nordstedt C, Seeger M, et al. 1996. Endoproteolysis of presenilin 1 and accumulation of processed derivatives in vivo. Neuron 17: 181-190.

Thinakaran G, Harris CL, Ratovitski T, Davenport F, Slunt HH, Price DL, Borchelt DR, Sisodia SS. 1997. Evidence that levels of presenilins (PS1 and PS2) are coordinately regulated by competition for limiting cellular factors. J Biol Chem 272: 28415-28422.

Tolia A, Chavez-Gutierrez L, De Strooper B. 2006. Contribution of presenilin transmembrane domains 6 and 7 to a water-containing cavity in the $\gamma$-secretase complex. J Biol Chem 281: 27633-27642.

Tolia A, Horre K, De Strooper B. 2008. Transmembrane domain 9 of presenilin determines the dynamic confor- 
mation of the catalytic site of $\gamma$-secretase. J Biol Chem 283: 19793-19803.

Tournoy J, Bossuyt X, Snellinx A, Regent M, Garmyn M, Serneels L, Saftig P, Craessaerts K, De Strooper B, Hartmann D. 2004. Partial loss of presenilins causes seborrheic keratosis and autoimmune disease in mice. Hum Mol Genet 13: $1321-1331$.

Tu H, Nelson O, Bezprozvanny A, Wang Z, Lee SF, Hao YH, Serneels L, De Strooper B, Yu G, Bezprozvanny I. 2006. Presenilins form ER $\mathrm{Ca}^{2+}$ leak channels, a function disrupted by familial Alzheimer's disease-linked mutations. Cell 126: 981-993.

van Es JH, van Gijn ME, Riccio O, van den Born M, Vooijs M, Begthel H, Cozijnsen M, Robine S, Winton DJ, Radtke F, et al. 2005. Notch $/ \gamma$-secretase inhibition turns proliferative cells in intestinal crypts and adenomas into goblet cells. Nature 435: 959-963.

Wakabayashi T, De Strooper B. 2008. Presenilins: Members of the $\gamma$-secretase quartets, but part-time soloists too. Physiology (Bethesda) 23: 194-204.

Wakabayashi T, Craessaerts K, Bammens L, Bentahir M, Borgions F, Herdewijn P, Staes A, Timmerman E, Vandekerckhove J, Rubinstein E, et al. 2009. Analysis of the $\gamma$-secretase interactome and validation of its association with tetraspanin-enriched microdomains. Nat Cell Biol 11: 1340-1346.

Wang Y, Chan SL, Miele L, Yao PJ, Mackes J, Ingram DK, Mattson MP, Furukawa K. 2004. Involvement of Notch signaling in hippocampal synaptic plasticity. Proc Natl Acad Sci 101: 9458-9462.

Wang B, Yang W, Wen W, Sun J, Su B, Liu B, Ma D, Lv D, Wen $\mathrm{Y}$, Qu T, et al. 2010. $\gamma$-Secretase gene mutations in familial acne inversa. Science 330: 1065.

Watanabe N, Tomita T, Sato C, Kitamura T, Morohashi Y, Iwatsubo T. 2005. Pen-2 is incorporated into the $\gamma$-secretase complex through binding to transmembrane domain 4 of presenilin 1. J Biol Chem 280: 41967-41975.

Weggen S, Eriksen JL, Das P, Sagi SA, Wang R, Pietrzik CU, Findlay KA, Smith TE, Murphy MP, Bulter T, et al. 2001. A subset of NSAIDs lower amyloidogenic $A \beta 42$ independently of cyclooxygenase activity. Nature 414: 212 216.

Weihofen A, Binns K, Lemberg MK, Ashman K, Martoglio B. 2002. Identification of signal peptide peptidase, a presenilin-type aspartic protease. Science 296: 22152218.

Weng AP, Ferrando AA, Lee W, Morris JPT, Silverman LB, Sanchez-Irizarry C, Blacklow SC, Look AT, Aster JC. 2004. Activating mutations of NOTCH1 in human T cell acute lymphoblastic leukemia. Science 306: 269-271.

Willem M, Garratt AN, Novak B, Citron M, Kaufmann S, Rittger A, DeStrooper B, Saftig P, Birchmeier C, Haass C. 2006. Control of peripheral nerve myelination by the $\beta$-secretase BACE1. Science 314: 664-666.

Wilson CA, Murphy DD, Giasson BI, Zhang B, Trojanowski JQ, Lee VM. 2004. Degradative organelles containing mislocalized $\alpha$ - and $\beta$-synuclein proliferate in presenilin-1 null neurons. J Cell Biol 165: 335-346.

Wines-Samuelson M, Schulte EC, Smith MJ, Aoki C, Liu X, Kelleher RJ III, Shen J. 2010. Characterization of agedependent and progressive cortical neuronal degeneration in presenilin conditional mutant mice. PLoS One 5: e10195.

Winkler E, Hobson S, Fukumori A, Dumpelfeld B, Luebbers T, Baumann K, Haass C, Hopf C, Steiner H. 2009. Purification, pharmacological modulation, and biochemical characterization of interactors of endogenous human $\gamma$-secretase. Biochemistry 48: 1183-1197.

Wolfe MS, Kopan R. 2004. Intramembrane proteolysis: Theme and variations. Science 305: 1119-1123.

Wolfe MS, Xia W, Moore CL, Leatherwood DD, Ostaszewski B, Donkor IO, Selkoe DJ. 1999a. Peptidomimetic probes and molecular modeling suggest Alzheimer's $\gamma$-secretases are intramembrane-cleaving aspartyl proteases. Biochemistry 38: $4720-4727$.

Wolfe MS, Xia W, Ostaszewski BL, Diehl TS, Kimberly WT, Selkoe DJ. 1999b. Two transmembrane aspartates in presenilin-1 required for presenilin endoproteolysis and $\gamma$-secretase activity. Nature 398: 513-517.

Wolfe MS, De Los Angeles J, Miller DD, Xia W, Selkoe DJ. 1999c. Are presenilins intramembrane-cleaving proteases? Implications for the molecular mechanism of Alzheimer's disease. Biochemistry 38: 11223-11230.

Wong GT, Manfra D, Poulet FM, Zhang Q, Josien H, Bara T, Engstrom L, Pinzon-Ortiz M, Fine JS, Lee HJ, et al. 2004. Chronic treatment with the $\gamma$-secretase inhibitor LY-411,575 inhibits $\beta$-amyloid peptide production and alters lymphopoiesis and intestinal cell differentiation. J Biol Chem 279: 12876-12882.

Xia X, Qian S, Soriano S, Wu Y, Fletcher AM, Wang XJ, Koo $\mathrm{EH}, \mathrm{Wu} \mathrm{X}$, Zheng H. 2001. Loss of presenilin 1 is associated with enhanced $\beta$-catenin signaling and skin tumorigenesis. Proc Natl Acad Sci 98: 10863-10868.

Yanagida K, Okochi M, Tagami S, Nakayama T, Kodama TS, Nishitomi K, Jiang J, Mori K, Tatsumi S, Arai T, et al. 2009. The 28-amino acid form of an APLP1-derived $A \beta$-like peptide is a surrogate marker for $A \beta 42$ production in the central nervous system. EMBO Mol Med 1: 223-235.

Yu G, Nishimura M, Arawaka S, Levitan D, Zhang L, Tandon A, Song YQ, Rogaeva E, Chen F, Kawarai T, et al. 2000. Nicastrin modulates presenilin-mediated notch/glp-1 signal transduction and $\beta$ APP processing. Nature 407: $48-54$.

Zhang C, Wu B, Beglopoulos V, Wines-Samuelson M, Zhang D, Dragatsis I, Sudhof TC, Shen J. 2009. Presenilins are essential for regulating neurotransmitter release. Nature 460: 632-636.

Zou K, Hosono T, Nakamura T, Shiraishi H, Maeda T, Komano H, Yanagisawa K, Michikawa M. 2008. Novel role of presenilins in maturation and transport of integrin $\beta 1$. Biochemistry 47: 3370-3378. 


\section{$\&_{\mathrm{CSH}}^{\infty} \&$ Cold Spring Harbor

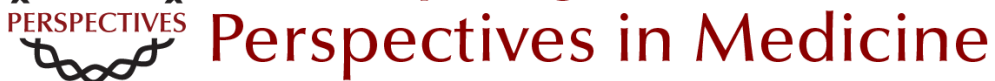

\section{Presenilins and $\gamma$-Secretase: Structure, Function, and Role in Alzheimer Disease}

Bart De Strooper, Takeshi Iwatsubo and Michael S. Wolfe

Cold Spring Harb Perspect Med 2012; doi: 10.1101/cshperspect.a006304 originally published online November 8, 2011

Subject Collection The Biology of Alzheimer Disease

Animal Models of Alzheimer Disease

Frank M. LaFerla and Kim N. Green

Neurovascular Dysfunction and Faulty Amyloid $\beta$

-Peptide Clearance in Alzheimer Disease

Abhay P. Sagare, Robert D. Bell and Berislav V. Zlokovic

Treatment Strategies Targeting Amyloid $\beta$-Protein Dale Schenk, Guriqbal S. Basi and Menelas N. Pangalos

The Ubiquitin-Proteasome System and the Autophagic-Lysosomal System in Alzheimer Disease

Yasuo Ihara, Maho Morishima-Kawashima and Ralph Nixon

Neurotoxicity of Amyloid $\beta$-Protein: Synaptic and Network Dysfunction Lennart Mucke and Dennis J. Selkoe

Proteolytic Degradation of Amyloid $\beta$-Protein Takaomi Saido and Malcolm A. Leissring

Brain Imaging in Alzheimer Disease Keith A. Johnson, Nick C. Fox, Reisa A. Sperling, et al.

Symptomatic and Nonamyloid/Tau Based Pharmacologic Treatment for Alzheimer Disease Paul S. Aisen, Jeffrey Cummings and Lon S. Schneider
Alzheimer Disease in 2020

David M. Holtzman, Eckhard Mandelkow and Dennis J. Selkoe

The Genetics of Alzheimer Disease Rudolph E. Tanzi

Fluid Biomarkers in Alzheimer Disease

Kaj Blennow, Henrik Zetterberg and Anne M. Fagan

Epidemiology of Alzheimer Disease

Richard Mayeux and Yaakov Stern

\section{Biochemistry and Cell Biology of Tau Protein in Neurofibrillary Degeneration \\ Eva-Maria Mandelkow and Eckhard Mandelkow \\ Biochemistry of Amyloid $\beta$-Protein and Amyloid \\ Deposits in Alzheimer Disease Colin L. Masters and Dennis J. Selkoe}

The Neuropsychological Profile of Alzheimer

Disease

Sandra Weintraub, Alissa H. Wicklund and David P. Salmon

Apolipoprotein E and Apolipoprotein E Receptors: Normal Biology and Roles in Alzheimer Disease David M. Holtzman, Joachim Herz and Guojun Bu

For additional articles in this collection, see http://perspectivesinmedicine.cshlp.org/cgi/collection/ 